\title{
The Economics of Badmouthing: Libel Law and the Underworld of the Financial Press in France Before World War I
}

\author{
VINCENT BIGNON AND MARC FLANDREAU
}

This article analyzes the economics of "badmouthing" in the context of the pre1914 French capital market. We argue that badmouthing was a means through which racketeering journals sought to secure property rights over issuers' reputation. We provide a theoretical study of the market setup that emerged to deal with such problems, and we test our predictions using new evidence from contemporary sources.

"A newspaper that wishes to make its fortune should never waste its columns and weary its readers by praising anything. Eulogy is invariably dull-a fact that

Mr. Alf had discovered and utilized."

A. Trollope, The Way We Live Now, 1875

"And did you threaten him with the newspapers?"

H. de Balzac, La maison Nucingen, 1837

B enjamin Franklin wrote that "glass, china, and reputation are easily cracked and never well mended." Anyone with a brand or public name is concerned with the costs of denigration by the press, because reputation is a source of rents. Libel laws exist to protect reputation, but-by the time compensation is obtained-irrecoverable losses have been incurred. False allegations linger despite efforts to publicize

The Journal of Economic History, Vol. 71, No. 3 (September 2011). (C) The Economic History Association. All rights reserved. doi: 10.1017/S0022050711001860.

Vincent Bignon is Economist, Bank of France, POMONE Department, DGEI-EMFI, 39 rue des Petits Champs, 75001 Paris, France. E-mail: vibignon@gmail.com. Marc Flandreau is Professor, Graduate Institute of International and Development Studies, 16, Voie Creuse, 1202 Geneva, Switzerland. E-mail: marc.flandreau@graduateinstitute.ch.

This article, written while Vincent Bignon was visiting professor at the Graduate Institute, benefitted generous funding from Yves Mirabaud, as part of his support of the Historical Imagination project. Part of this article was written while Bignon was a visiting scholar at the Mercatus Center at George Mason University, where the hospitality of John Nye is gratefully acknowledged. We are thankful for support and help from the librarians of the Graduate Institute in Geneva, in particular from Martine Basset and Yves Corpataux, and to the archivists of the Société Générale and the Banque de Paris et des Pays-Bas for their help and patience. We also thank Pierre Turgeon for excellent research assistance. For useful comments and criticism, we thank Daron Acemoglu, Fabio Braggion, Régis Breton, Jin-Zhao Chen, Robin Derby, David Dobrin, Claudia Goldin, Andrea Goldman, Eric Hilt, Naomi Lamoreaux, and Noel Maurer. We also thank Gabriel Geisler for directing our attention to an informative piece. We are grateful to Melanie Aspey of the Rothschild Archive for disclosing to us confidential

${ }^{1}$ Quoted in Whiting, Early American Proverbs, p. 176. 
any court rulings that the libeled party may have secured. Papers thus have claims on a security issuer's reputation, because reputation is pretty much what the press makes of it. This externality cannot be easily addressed or insured against, given the built-in moral hazard. Furthermore, there is a trade-off between libel law and freedom of speech. Full freedom of speech gives more people the opportunity to speak the truth; but this also creates the problems described here as it becomes harder to secure protection from being denigrated.

"Badmouthing" here covers the threat to print negative things (for extortion purposes) as well as the implementation of such threats. Indeed because reputation is valuable, it is possible to turn badmouthing into a racket. Faced with the threat of badmouthing victims are tempted to pay to prevent damaging rumors from circulating. Badmouthing is easy. It is based on making things up and threatening to publish them. Because they have a readership, newspapers are well positioned to promote such fabrication. They need not actually make allegations (since these could run afoul of libel law); rather, a paper need only imply, suggest, or let it be understood that something is wrong and let the rumor grow. Many racketeering cases do not need involve open accusations. When a borrower comes under threat, some newspapers can suspend reporting on it. Concern is then communicated by lack of coverage. The "embargoed" firms have an incentive to approach newspapers about actually paying for coverage. Badmouthing is also hard to curb in a society where freedom of speech prevails, since it is hard to distinguish from the free expression of negative views.

Some situations are especially conducive to such problems: firms issuing new securities, experiencing financial difficulties, or selling risky technology are easy targets. Detection of badmouthing is difficult because payoffs can take many different and legal forms: as soon as some media is responsible with providing information, the problem can

information (not reported in this article) suggesting that the story we tell has a modern counterpart. We thank the participants in the Third Financial History Workshop in Tilburg University (1 April 2009), the UCLA Department of History Spring 2009 Colloquium Speaker Series (30 April 2009), the 13th Annual Conference of the International Society for New Institutional Economics at the University of California at Berkeley (18-20 June 2009), the Harvard University Economic History Workshop (13 November 2009), the Financial History Seminar series at Cambridge University (30 November 2009), the Economic History Seminar at the University of Geneva (20 May 2010), the Swiss Clio meetings (17 September 2010), and the EHA meetings in Evanston, IL (25 September 2010) for their comments. We thank our referees for comments and criticism. Lastly, we are grateful to the JOURNAL's editor for his generous patience and excellent writing suggestions. The views expressed herein are those of the authors and should not be interpreted as reflecting those of the Banque of France or the Eurosystem. The usual disclaimer applies. 
arise. Historically, a frequent target of accusations of "badmouthing" is the rating agencies (although at a broader level, the matter is a recurrent one with the financial press at large). This began with criticism of the agencies' nineteenth-century American forerunners (the "mercantile agencies"), which were sometimes charged with the accusation that firms who refused to subscribe would receive poor ratings. ${ }^{2}$ Recently, Hannover Re (a German insurer) charged that Moody's had tried to force it to purchase a rating and that the insurer's resistance led Moody's to report an unsolicited negative rating (Re claimed that two other rating agencies it had employed reported a favorable outlook). ${ }^{3}$

How can potential victims manage this problem? We explore how market solutions emerged in Paris from 1870 to 1914. While the issues raised by badmouthing are general, there are three reasons for choosing this setting for our study. First, the Law of 1881 gave the press both free speech and free entry. ${ }^{4}$ Second, the period is usually portrayed as being rife with defamatory rackets and related abuses by the press against banks, borrowing governments, and firms. ${ }^{5}$ Graphic and informative details can be drawn from a variety of sources including L'humanité (a communist newspaper). Between December 1923 and March 1924 it showed how the czar paid nearly 5 million pre-World War I FF (1 million pre-World War I USD) to the French press between 1904 and 1907. Finally, despite badmouthing, the Paris financial market remained the second most important international capital market in the world. Paris' market capitalization as a share of GDP was close to 100 percent, and Paris competed with London to issue foreign government debt. ${ }^{6}$ Badmouthing must have been, to some extent, tamed.

Other modern papers have examined the impact of a free press on corruption and quality. ${ }^{7}$ In this literature, the press helps by monitoring managers and policymakers and by reducing frauds. By assumption, a free press tells the truth and reports wrongdoings. Our article takes a

\footnotetext{
${ }^{2}$ In the words of one observer: "What [mercantile agencies] desire is to drive the man within their own in closure, and force him to become a subscriber to their institution." Brooklyn Eagle, "Agencies," 15 November 1873, 2.

${ }^{3}$ Alec Klein, "Credit Raters' Power Leads to Abuses, Some Borrowers Say," Washington Post, 24 November 2004. See also Jennifer Levitz, "Moody's Sued in Ratings Case," Wall Street Journal, 26 March 2009.

${ }^{4}$ Albert, "La presse française."

${ }^{5}$ Marinitsch, La bourse; Lajeune-Vilar, Les coulisses; Mouthon, Bluff au chantage; Raffalovich Abominable vénalité; Ageron, "La vénalité de la presse française"; and Jeanneney, "La vénalité."

${ }^{6}$ Rajan and Zingales, "Great Reversals."

${ }^{7}$ Gentzkow, Glaeser, and Goldin, "Rise of the Fourth Estate"; Petrova, "Newspapers and Parties"; McMillan and Zoido, "How to Subvert"; Dyck, Volchkova, and Zingales, "Corporate Governance Role"; Besley and Prat, "Handcuffs"; Gentzkow and Shapiro, "Media Bias"; Djankov et al., "Who Owns"; and Baron, "Persistent Media Bias."
} 
different perspective. A free-press regime also complicates the court enforcement of libel cases. Thus the current literature deals with truth in the market for news, and the risk that true facts remain concealed. We are concerned with the risk that false (and harmful) claims circulate. Statistical theory shows that there is a relation between the incidence of the two problems (known as type I and type II errors). Increasing the stringency of libel law (raising the cost of defamation) reduces false claims but increases the risk that true claims will not be publicized. In this broader context, it may be optimal to tolerate a certain degree of defamation. We leave the normative issue of the optimal amount of libel punishment aside, and focus on market solutions that contain denigration. ${ }^{8}$

To understand how the market dealt with the risk of badmouthing, we analyze the organization of the French press and discuss instances of defamatory racket. We find that certain newspapers specialized in disinformation and racketeering. These were the smaller and less reputable papers, which we call "bad" or "zombie," that appeared to wage a press campaign only to be discontinued afterwards. Yet since they were small and lacked reputation, any one of these bad papers did not wield much influence: they were only dangerous when they coordinated their attacks. This created an incentive for bad papers to become more organized and at the same time, their targets had an incentive to organize themselves. We find that, to control the damages of badmouthing, corporations, underwriting banks, and governments turned to quasi-formal intermediaries, known as "publicity brokers," who acted as delegated monitors (essentially mafia bosses) and replaced bilateral sanctions with multilateral, intertemporal ones.

Another finding concerns the implications of our theory for newspaper revenues. We show that the risk of bad publicity induces targets to seek press coverage from more prestigious sources of information. ${ }^{9}$ As a result, space in good papers is scarce, and they can charge information providers. Thus the threat of badmouthing may be viewed as the solution to the free-rider problem that underlies any provision of high-quality information: the noise generated by badmouthing threatens not only investors but also borrowers, thus the "good" press enjoys a windfall. This analysis can go a long way toward resolving why rating agencies, which early on only charged the purchasers of their "manuals," successfully switched to a regime where issuers of securities were also

\footnotetext{
${ }^{8}$ Garoupa, "Dishonesty"; Bar-Gill and Hamdani "Optimal Liability”; and Dalvi and Refalo, "Economic Analysis."

${ }^{9}$ Modiano, La presse pourrie, p. xi.
} 
charged. ${ }^{10}$ Proposals suggesting that agencies should now switch back to the former regime miss an important aspect of the current setup: it is a natural market outcome and, in many respects, may be a desirable one. ${ }^{11}$

Because of its underground nature, badmouthing has left no systematic trace. Using published material and archival evidence, we have gathered entirely new data sets. First, we document the evolution of the population of financial newspapers in Paris (and London) for the period 1870-1913. We rely on so far unexploited yearbooks (such as the Catalogue des Journaux Imprimés and the Annuaire de la presse) to compute the longevity of the financial weeklies. We also collected individual information on newspapers' periodicity and price per issue. For a few sampled newspapers, we also collected the advertising surface and the price per line of advertisement to construct an estimate of advertising revenues. Using a variety of sources such as leaks in newspapers and bank archive, we also gather evidence on actual bribes paid for a number of security issues and compare these to other issuance costs such as the fees charged by underwriting banks. Finally using secondary sources, memoirs by journalists, police reports from archives, and a number of other documents, we have striven to paint a complete and accurate picture of shadowy organizational features our account suggests were important.

We begin with the legal background (and contrast it to Great Britain's), provide canonical examples of badmouthing, report statistical information, and document the rise of what we call a "zombie press." Section II provides a theory of badmouthing that relies on several strands of literature. In the next section, we establish facts that are consistent with the predictions underlying our intuitive theory of the market for fabricated news. Section IV, finally, provides a positive exploration of the costs of badmouthing. Relying on information disclosed in the press in several instances of racket, which we matched with material from bank archive, we construct estimates of badmouthing expenditures. The small numbers we get are consistent with our central claim that badmouthing remained subdued. On the other hand, exploring the distribution between good and bad outlets, we find evidence of nontrivial line losses (a substantial share of money reaching the less reputable outlays).

\footnotetext{
${ }^{10}$ See Cantor and Packer, "Credit Rating Industry"; Smith and Walter, "Rating Agencies"; and Byoun and Shin, "Unsolicited Credit Ratings." For a historical description of rating agencies, see Sylla "Primer"; and Flandreau, Gaillard, and Packer, "Rating Agencies."

${ }^{11}$ A contemporary discussion of feasible charging structures can be found in Raffalovich, L'abominable vénalité, p. 207.
} 


\section{LIBEL LAW AND BADMOUTHING: HISTORICAL BACKGROUND}

\section{Libel Law and the Era of Journalistic Freedom in France (1871-1914)}

The period from 1870 to 1914 is usually portrayed as the heyday of journalistic freedom in France. Between 1851 and 1870 Napoleon III limited the political freedom of the press: censorship controlled news content, high stamp duties discouraged entry, and new titles had to be officially sanctioned. ${ }^{12}$ The advent of the Third Republic in 1870 ushered in a significant liberalization. Supervision was relaxed and entry costs were lowered. Pressure by the left-of-center Radicaux led to more lenient implementation of libel laws. After this party won the elections of 1876, the press was given full freedom in the Law of 1881.

The new law's self-professed aim was to check any executive control of the content of newspapers, and it abolished all remaining entry barriers. ${ }^{13}$ A key aspect of the law is that it transferred political libel cases from correctionnelle tribunals, which were ruled by professional judges who could be influenced by the government, to assises courts - that is, popular juries. Historians have emphasized that the new statute of 1881 (described as France's "First Amendment") encouraged a violence of language that was unmatched in other countries.

Compare now with Britain. There the Campbell Act of 1843 was in force and it had a strong anti-badmouthing bias. First, the act punished "plain" libel with one year in an ordinary prison. Malicious libels (known to be false), could lead to three years' imprisonment, including hard labor. Second, the act explicitly punished threatening to publish a libel (or to abstain from publishing anything) with intent to extort with forced labor for up to three years. ${ }^{14}$ Third, the "defense of truth," which allowed defendants to prove their accusation true, could only be invoked if publication of the libel was in the "public benefit." Finally, those defendants convicted of libel had to bear the plaintiff's legal expenses. ${ }^{15}$

Even under Napoleon III, France was more tolerant of malicious libel against corporate interests and the Law of 1881 did not provide for higher penalties. Penalties were systematically smaller than those prevailing in Britain for a similar tort (up to six months or one year,

\footnotetext{
${ }^{12}$ Palmer, Des petits journaux; and Albert, "La presse française."

${ }^{13}$ For a classic discussion, see Albert, "La presse française." Note that the process had started earlier. Judges are said to have anticipated on the new law, providing increasingly softer interpretations of existing provisions in the period before 1881 .

14 "An Act to Amend the Law Respecting Defamatory Words and Libel," CAP. XCVI, Anno Sexto \& Septimo, Victoriae Reginae.

${ }^{15}$ See Koss, Rise and Fall, for an account of the British experience.
} 
depending on the violation). Moreover, Article 35 of the Law of 1881 allowed the defense of truth to be used against directors or board members of industrial, commercial, or financial enterprises offering securities to the public. ${ }^{16}$ One could thus print any insulting or denigrating statement against corporate executives-provided it was based on "facts." Effectively, the law provided no checks on slander.

Given this situation, did anyone manage to find solutions to rampant badmouthing? Social historians have seen tighter libel laws in Britain as leading to the early disappearance of duels in Britain and their continuation in France. ${ }^{17}$ In French literary and political circles, duels were used to deal with badmouthing; in fact, some leading newspapers had in-house facilities to train for fencing. ${ }^{18}$ The early years of the Annuaire de la presse, the main statistical source for information on newspapers, also reported on the "most important duels." Yet risking one's life to defend a reputation may have been too chivalrous a deed for bankers and businessmen. As reported in the Annuaire, they rarely dueled, and none were killed. ${ }^{19}$

Figure 1 displays the numbers of economic and financial newspapers in Paris and London between 1874 and 1913. These numbers offer a stark contrast. Our sources for France are the Catalogue des journaux imprimés (1875/76), La publicité en France (1878-1880), and the Annuaire de la presse (1881-1914). ${ }^{20}$ Each organizes newspapers by subject, and we counted the number of papers listed under finance and économie politique (political economy). For England, the Tercentenary handlist of English \& Welsh newspapers, magazines \& reviews lists all the periodicals published for at least one year in London between 1620 and $1920 .^{21}$ Two facts are evident from Figure 1. First, between 1874 and

\footnotetext{
16 "La vérité des imputations diffamatoires et injurieuses pourra être également établie contre les directeurs ou administrateurs de toute entreprise industrielle, commerciale ou financière, faisant publiquement appel à l'épargne ou au crédit" (Law of 1881, Article 35).

${ }^{17}$ Simpson, "Dandelions."

${ }^{18}$ Duels were tolerated, and if conventions were scrupulously respected (number and qualification of witnesses, rules for choosing weapons, etc.), killing ones' opponent did not lead to sentences.

${ }^{19}$ The two instances we found in Dujardin's 1891 Annuaire du duel occurred in 1880 and 1882. All told, there were 38 duels in 1880 and 58 in 1882. The 1880 duel opposed Arthur Meyer, director of Le Gaulois, to the banker Gaston Dreyfus. When Meyer was wounded, the fight was stopped. While fighting Dreyfus, Meyer also claimed he had been insulted by Mr. Lange (another banker) whom he challenged to a duel. Lange declined as he did not care if he was "killed" in the press.

${ }^{20}$ The exact title of the last yearbook was changed twice. Between 1892 and 1905 as Annuaire de la presse française et du monde politique, and then as Annuaire de la presse française et étrangère et du monde politique.

${ }^{21}$ As for London, the source we use did not classified newspapers by specialty and it only listed which newspapers appeared each year. To obtain the number of financial periodicals published
} 


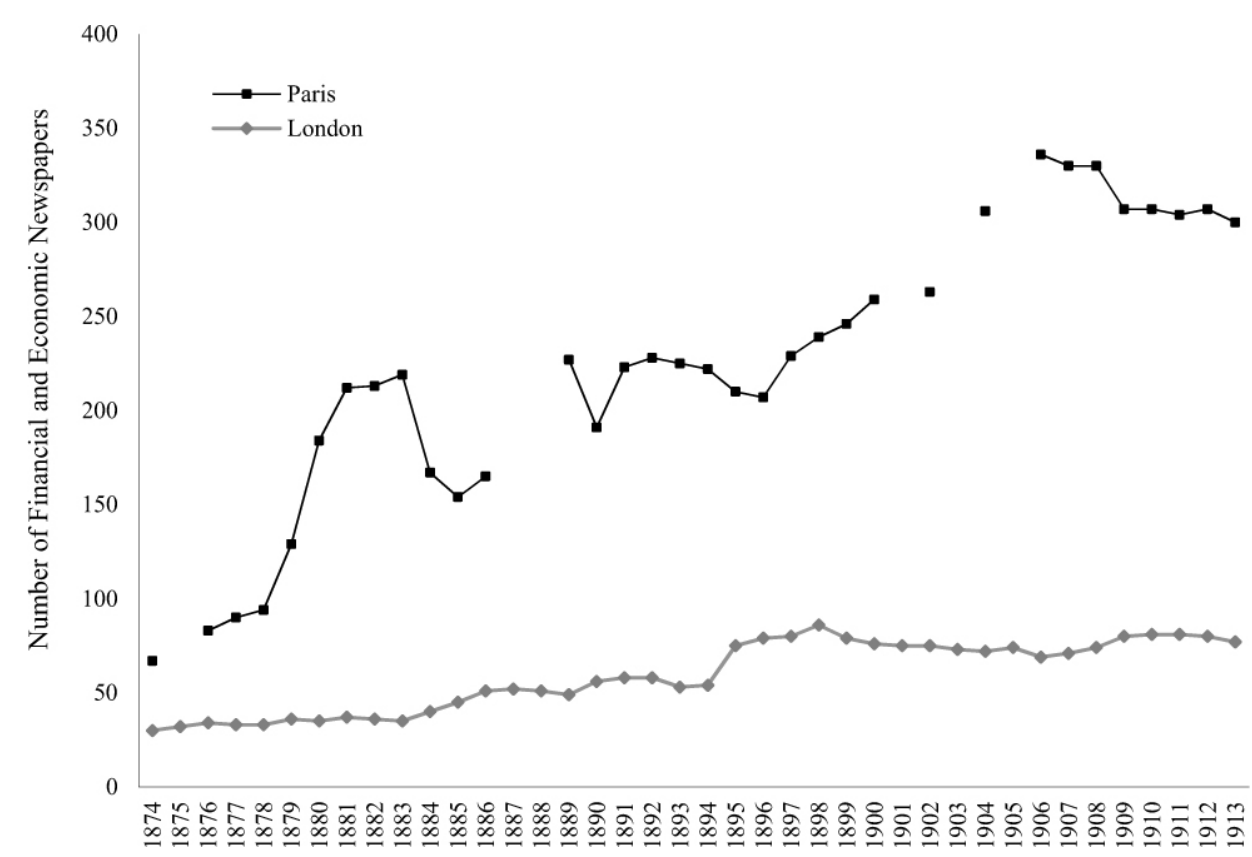

\section{FIGURE 1 \\ NUMBER OF NEWSPAPERS SPECIALIZED IN ECONOMICS AND FINANCE IN FRANCE AND BRITAIN}

Source: Authors' computations. French Data are from the volumes of the Catalogue des Journaux Imprimés $(1875,1877)$ edited by Gébé, La publicité en France $(1878,1879,1880)$ edited by Mermet, and the Annuaire de la presse (1881-1914), edited by Mermet (1881-1891), D'Avenel (1892-1904/05), and Bluysen (1907-1914). Each volume appeared at the beginning of the year, and then reflected the number of newspapers published in December of the preceding year. English data are from the Tercentenary Handlist of English and Welsh Newspapers, Magazines, and Reviews (1920).

1880 there was a dramatic increase in French financial media (from about 67 to about 200). Comparable London media increased more slowly. Second, the Paris totals are astonishingly high - around 1900 there were more than three times as many newspapers as in London. If Parisians were not so passionate about financial news, could it be that not every one of the 310 papers of 1913 was a bona fide publication?

each year, we identified both which papers were in finance and political economy and which were (or were not, respectively) in operation in a given year. The source for London required to proceed by hand (no journal category given). To establish the finance category, we identified by name and through external checks all economics and finance related journals (but excluded insurance journals to make it more congruent to the French data). 
Anecdotal evidence leans towards the latter explanation. Many Parisian papers had pseudo-addresses, existed only episodically, and/or cannot be found in any library on earth. Many of those for whom the Bibliothèque Nationale has complete runs lack continuity. ${ }^{22}$ Periodicity, names, or content when available leave us to suspect that most participated in racketeering operations before going dormant until they were resurrected by the same director or a friend under the same guise or in a slightly different reincarnation (same address but modified name or vice versa). With no pun intended, they only existed "on paper!"

The difference between newspaper demographics in London and Paris comes from differences in libel law. With weak libel law, there was a greater benefit in France to engage in badmouthing rackets. Therefore, one benchmark estimate of the number of newspapers that would have existed in Paris under a counterfactual scenario of tighter libel law in France may be provided by comparison with London. It is unclear how many finance and economics newspapers are needed, but 50 to 80 newspapers in London hardly stifled Britain's economic development. Figure 1 thus provides a suggestive lower bound for the number of newspapers that existed mainly as instruments of rackets. In 1900 Paris had 250 of these, a large number. ${ }^{23}$

\section{Examples of Badmouthing}

Two examples help define badmouthing. A famous instance of the badmouthing racket involved a Russian government representative in Paris (Arthur Raffalovich). His correspondence was published in the 1920s by the French Communist Party's newspaper L'humanité (with help from the Soviets). It shows that the French press had extracted substantial fees from the Czarist regime as it sought financing during and after the Russo-Japanese War of 1904/05. At the war's outset, Russia's had a moderate debt, an impeccable record for paying coupons-financially speaking, there was not much to report upon, except that Russia's finances were of "first order." 24 But Russia was involved in a difficult war, and its government knew it would need foreign markets to raise resources. Since

\footnotetext{
${ }^{22}$ For instance, a "weekly" paper might not be published every week, and number 12 could appear several months after number 11. In the first semester of 1909 the weekly Moniteur des intérêts matériels francais appeared only on March 15 and 22, the next issue was February 10, 1910. The weekly Le messager du rentier put out 16 issues during the same period, thus failing to publish ten issues.

${ }^{23}$ This is a lower bound because, despite higher penalties, problems of badmouthing were widespread in England, too. See Trollope, Way; Duguid, Money Article; and Porter, "Trusted Guide."

${ }^{24}$ Flandreau, "Caveat Emptor"; as Raffalovich (L'abominable vénalité, p. 407) complained in one letter: "we [Russia] are not in the same situation as Argentina, or Brazil."
} 
Britain had sided with Japan, Russia would have to sell new debt issues in Paris. Any account in the Paris press suggesting that Russia was "living beyond its means" or "on the "breaking point" would create a sensation. Moreover, Russia's enemies were prepared to subsidize such rumors. ${ }^{25}$ The Raffalovich correspondence shows papers approaching Russian representatives in Paris. It appears that Russia had no choice but to forestall bad press with purchase of publicity and bribes. Serious papers also received money. Jean-Noël Jeanneney concludes that the venality of the financial press had demoralizing effects on journalism at large. ${ }^{26}$

Reading the press between the lines, we can find hundreds of instances of badmouthing rackets: they are easily located in semi-periodical newspapers. Consider the example of La semaine économique et financière, an occasional financial weekly. On January 221912 this paper ran a story about the Banque Suisse et Française, which was raising capital in Paris. The story encouraged investors to be cautious. No real allegation was made; rather, reference was made to a "troubled past" and to the bank's being less "Swiss-French" than "German-French" and, in fact, "more German than French" (the journalist inferred this from the names of directors). In the pre1914 climate, being "more German than French" was tantamount to being owned by the hereditary enemy. The story claimed that $L a$ semaine - unlike other newspapers that "knew nothing but praise"felt "compelled" to forewarn readers and that one "could never be too prudent." The article concluded with an ominous warning of more details to come. The publisher was exploiting the libel law's "loophole": published statements were literally true and hid the racket behind Article 35. The paper never published any "further details"; whether the prey did or did not cough we cannot be sure.

These cases share several features. First, the rumor is cheap because it does not require any investment in information. Second, a rumor is started precisely when the target is about to need capital market access (to finance a war or to fund a capital increase). Finally, each allegation enjoys "defense of truth" immunity because they are literally "true" and target managers: Russians were actually attacked by Japan and lost part of their fleet; and Swiss German names do sound German.

\footnotetext{
${ }^{25}$ These enemies included outside political rivals (such as Germany), domestic opponents to the czar's autocratic rule, and international lobbies trying to protect oppressed Jewish minorities (see Miliukov, Russia and Its Crisis).

${ }^{26}$ Jeanneney, "La vénalité."
} 
Payments, Intermediaries, and Participants

Journalists were paid off in many ways, and the law was no obstacle. Some financial journalists received monthly stipends, others stock options. ${ }^{27}$ Publishers could be pacified by buying space in newspapers for instance by publishing long columns of technical information (for example, results of the drawings of bonds for amortization). During 1905/06 Le rentier devoted about two pages (out of sixteen) to information on Russian bonds - all paid for by Russian authorities. ${ }^{28}$ Similarly, banks had details of their services, deposit rates, provision of safes, or minutes of their board meeting published in newspapers. Archives provide proof of interest-free loans to publishers that were never reimbursed. $^{29}$

The evidence suggests that every newspaper was involved in one way or another. It also suggests that an entrepreneur about to launch a new project could expect the visit of individuals offering "help"-thinly disguised badmouthing threats. It also seems that different newspapers relied on different racketeering techniques. Papers with a relatively high reputation were mollified with purchases of advertisement space, and Lysis actually calls publicity a "gentlemanly form of racket." 30 Outright threats of badmouthing were made by journalist-thugs who having found a rumor and prey, could turn to printers who offered ready-made four-page papers with news taken from a variety of open sources. ${ }^{31}$ These could be had at a cost close to the price of the paper on which they were printed. The racketeer would provide the information for the front page and a "newspaper" was born: all that was left was to hawk it in the street.

Contemporaries give the impression that financial gossip was well organized. It had its market place. Rumors were traded in a known spot, under a colonnade on the side of the Paris Bourse, colloquially known as the Académie de Chant (in English, the badmouthing academy). ${ }^{32}$ There even existed racket intermediaries who could be called upon by the target

\footnotetext{
${ }^{27}$ For stipends, see Marinitsch, La bourse, p. 296; Lajeune-Vilar, Les coulisses, p. 62; and Leroy-Beaulieu, L'art, p. 254. For stock options, see Lajeune-Vilar, Les coulisses, p. 51; and D'Avenel, "Le mécanisme," p. 643.

${ }^{28}$ Authors' own estimates.

${ }^{29}$ A file (box B3323) in the archives of the Société Générale indicates that it made a loan to M. Chavanon, director of L'information. A few years later, when the department for judicial affairs tried to secure reimbursement, Chavanon simply ignored the request. Documents show that the bank manager ordered the lawyers to stop asking for repayment, which suggests that Chavanon had paid a visit to the bank's management.

${ }^{30}$ Lysis, Contre l'oligarchie financière, p. 48.

${ }_{31}^{31}$ Lajeune-Vilar, Les coulisses.

${ }^{32}$ Ibid., p. 53
} 
prey to distribute monies. ${ }^{33}$ Even though major borrowers or banks and major press outlets could have settled directly, many payments to the press were managed by agents de publicité financière (advertising brokers). No study was ever made of these brokers, and they have left no archives. However, they were monitored by the police whose archives contain interesting (albeit limited) material. ${ }^{34}$ They also appear in the records of banks and newspapers. Secondary accounts suggest that publicity brokers centralized the distribution of bribes, in this world of unwritten contracts. ${ }^{35}$

That the police monitored but did not interfere implies that the executive branch of government gave tacit support to this arrangement. In fact, government officials were sometimes found among racketeers. Moreover, the press was a vehicle for laundering bribes: compelling a target to buy ads in a newspaper was legal, whereas payments without counterpart services were not. ${ }^{36}$ Antoine Lefébure remarks that tax inspectors who came across "publicity" or "press" expenses "smiled and moved on." 37 This, he indicates, means that bureaucrats refused digging too deeply to avoid the risk of discovering disguised payments to the executive. In the Russian case we saw earlier, Raffalovich was first approached by the head of the Paris Bourse and then called by senior staff from the finance ministry. Senior members of the stock exchange tried to influence Raffalovich's list of newspapers to be bribed. One can surmise that they advocated for clients and political friends. There is also evidence that senior politicians instructed the Russians to pay certain papers, who then used the bribe monies to buy votes in parliament. ${ }^{38}$ Finally, Lysis claims that publicity brokers fulfilled an "important social function" because they had tight connections with politicians.

\section{BADMOUTHING IN THEORY}

Badmouthing has not been well analyzed by formal models. In what follows, theoretical concepts are used in a pragmatic way. They are adapted to context and adjusted to guide the narrative. We want to develop analytic inferences useful to organizing data in the next section. Our starting point is the stylized fact that liberalization of speech in the $1870 \mathrm{~s}$

\footnotetext{
${ }^{33}$ Ibid., pp. 54ff; and Marinitsch, La bourse, pp. 292-96.

${ }^{34}$ More detail can be found in the French National Archives (F/7/12842; Société Générale des Annonces, report 30 May 1914).

${ }^{35}$ Lajeune-Vilar, Les coulisses; and D'Avenel, "Le mécanisme," p. 642.

${ }^{36}$ Lajeune-Vilar, Les coulisses, pp. 59-62. See Ellschot, Lijmen, for a novel describing this mechanism in 1920s Flanders.

${ }^{37}$ Lefébure, Havas, p. 211.

${ }^{38}$ Raffalovich, L'abominable vénalité; and Ageron, "La vénalité de la presse française."
} 
and its consolidation by the landmark law of 1881 coincided with a dramatic increase in the number of newspapers. Reducing entry costs and deterring libel suits encouraged the entry of low quality papers: in other words, the value of the badmouthing option increased. Owning a bad newspaper was like owning a claim on those states of the world when and where racketeering paid. ${ }^{39}$

The resulting situation amounts to a lemons problem. ${ }^{40}$ Readers understand that many of the papers published are of poor quality and they have trouble telling the badmouthing ones from the rest. Therefore readers are not prepared to pay much for newsprint. Papers willing to produce high-quality information are the ones that face a loss. One equilibrium outcome is that only low-quality papers appear. The alternative is that good papers can signal their worth and commit to maintaining their quality.

The issues of reputation and signals are central. Carl Shapiro suggested high-quality sellers would invest in reputation by behaving well and this would make it costly for them to cheat the public. The reason is that cheating would destroy the earlier investment in reputation. ${ }^{41}$ Following this, a large theoretical literature has analyzed when and how high- and low-quality products may coexist. One key element is that, beyond patience (for only patient sellers will invest in quality) market share matters. Indeed agents with a larger market share have more to lose, other things being equal. ${ }^{42}$

The seller who invests in quality must be able to tell his customers he has done so. As Michael Spence showed, the signals need not be perfect. As long as the signal is positively correlated with quality, the investment in quality has value and is associated with higher equilibrium prices. ${ }^{43}$ Another type of signal studied in the literature is publicity. Phillip Nelson study of "experience goods" explores what happens when quality can be assessed only after purchase. He argues that publicity for such goods signals a quality product because only quality products will generate (through future purchases) the kind of revenues that warrant publicity expenditure in the first place. ${ }^{44}$

\footnotetext{
${ }^{39}$ Lajeune-Vilar (Les coulisses, p. 53) cites the decline of entry costs and the increase in financial optimism as reasons for the association between the 1881 crisis and the boom in newsprint.

${ }^{40}$ Akerlof, "Market for 'Lemons'."

${ }^{41}$ Shapiro, "Returns to Reputations."

${ }^{42}$ Diamond, "Reputation Acquisition"; and Gorton, "Reputation Formation."

${ }^{43}$ Spence "Job Market Signaling."

${ }^{44}$ Nelson, "Consumer Behavior" and "Advertising as Information."
} 


\section{An Intuitive Model}

These insights help explain the equilibrium coexistence of newspapers of high and low quality and why badmouthing may have had a limited reach. Good, reliable papers were supported by the rents and other features they earned from their investment in quality. For such papers, the short-term benefits from racketeering are less than the long-run cost of brand damage. In other words, reputation concerns prevented papers with a name from overt badmouthing (saying bad things about good concerns). If they circulated views that could later be exposed as wrongful, they would destroy their own reputations and face the consequent pecuniary losses. ${ }^{45}$

The same logic leads ordinary newspapers to make different choices. They do not have a reputation and as a result they are prepared to try to "fool" consumers (readers) to extract money from preys. Since racketeering is free entry, the equilibrium condition is that the wage opportunity cost of racketeering equals the expected gain from the badmouthing racket. France's liberal libel regime spawned an army of fly-by-night papers who are only printed when an opportunity for badmouthing materializes. We will call such newspapers "zombies" for they come to life only to serve the racketeers. Thus, papers with the greatest capacity to circulate rumors (because they have a regular readership and credibility) are also the least inclined to engage in racketeering for fear of losing their readers. This, we argue is what, as a first approximation, takes care of badmouthing. ${ }^{46}$ But there are other interesting theoretical issues.

While established papers have limited incentive to lie (being found out would cost them money), they nonetheless have some leverage over issuers, because they are valuable information outlets. Reliable press outlets can induce issuers to pay by making no mention of them. ${ }^{47}$ To avoid the silence firms will pay to secure coverage by a reliable paper. A reliable paper could have charged for printing an opinion, as rating agencies do nowadays, or it could have required the issuer to buy advertising space. Both options are consistent with the view that reliable

\footnotetext{
${ }^{45}$ This hypothesis has been questioned in experimental settings, but economic historians have ascertained that mistrust in one's newspaper may lead to voting against that newspaper's recommendations (Bloch, L'Etrange défaite, p. 163).

${ }^{46}$ Note that this also implies that good newspapers have an incentive in bad newspapers being aggressive, since this generates revenue. And since good newspapers have a dominant market position, they can actually subsidize badmouthing.

${ }^{47}$ For example, one financial newspaper (Messager de Paris) told readers that they ought to "read between [the] lines" and understand that in some cases "no report is equivalent to a forceful blame"; quoted in Albert, "La presse française," p. 172. Bignon and Miscio, "Media Bias," report evidence of information suppression.
} 
certification is a scarce resource. It implies that the ability to charge readers and the ability to charge issuers are complements. Indeed, buying ads in a good paper ensures the publisher's loyalty to the firm. There is a thin line between this and the rating agency racket described above and we think of our analysis as providing theoretical motivation for rating agencies' "issuer pays" model. An interesting aspect of this mechanism is the windfall it creates: potential targets use ads to protect themselves individually. In aggregate, this provides resources to the reliable newspaper and creates a natural barrier against zombies.

A second set of insights comes from two-sided market models. These theories explore situations in which "platforms" court two (or more) parties that use the platform to interact with each other. For instance, the paper (the platform) reports financial information on firms (one party), and investors (the other party) use that information to place their money. The platform chooses what each party pays so that everyone participates. Attracting many agents on one side of the market increases what agents on the other side are willing to pay. ${ }^{48}$ These models also consider competition between platforms. A critical requirement for efficiency is that there be enough competition between platforms in order to prevent rent extraction. In other words, free entry in the market for news is of utmost importance. At the same time, we have seen that the reliable papers can never be fully competitive (investments in reputation are sunk costs) and they must therefore extract some rents.

In this light, the proper way for a firm to deal with threats of badmouthing would seem to be to buy advertising space in enough reliable papers and ignore the zombies. However, preys had limited knowledge of the quality of each paper. With close to 300 financial journals in addition to the political press, it was difficult for a nonspecialist to sift for serious newspapers. An issuer had to respond correctly when a journalist came knocking (whether to kick him out or to cough up) and only a specialist could gauge each and avoid the costs of misjudging papers. Beyond information asymmetries, we have contagion. Exploiting an already existing rumor could make rackets more successful. According to André Lajeune-Vilar: "In the Paris press, when one or two papers start a campaign all others follow suit the day after."49 The externality might have sustained the trading of rumors under the colonnade of the Bourse where zombie predators organized campaigns. Last, there was the problem of monitoring, that is, making sure that bribed newspapers (of high or low quality) held up their end of the bargain. ${ }^{50}$

\footnotetext{
${ }^{48}$ Rochet and Tirole, "Two-Sided Markets."

${ }^{49}$ Les coulisses, p. 76.

${ }^{50}$ We mentioned stock options earlier. Their traction is that they are self-enforcing. Because
} 
Large, repeat issuers could find it worthwhile to develop their own expertise, but most firms could not do so. The market needed agents who could monitor the newspapers. The problem was one of limited enforcement (because of the Law of 1881) ${ }^{51}$ Typically when the law provides no remedy for nonperformance, a buyer (prey) needs to be sure that the seller (newspaper) will not cheat on the contract. In our badmouthing problem, we expect intermediaries would arise to coordinate the payment of bribes and to see to it that newspapers implement their end of the informal contract.

\section{Some Inferences}

Our theoretical tour yields four important "predictions": (1) Newspapers with longer horizons invest in quality which we take to be reliability. They make greater efforts to secure a reputation, have probably a greater capital, etc. and as a result, they are expected to charge readers more: we expect to find a significant positive correlation between financial newspaper price and longevity; (2) Reputable papers extract more revenue both from information seekers (readers) and from information providers (firms). Relative to unreliable/bad newspapers, they charge higher prices to their readers, and they generate larger advertising revenues; (3) Information intermediaries should emerge. The reason is commitment problems for both good and bad journals. Those intermediaries discipline badmouthing and nonmouthing activities with a system of intertemporal rewards and punishments and in order to perform this duty efficiently, we predict they must be few and stable; and (4) Payments to newspapers are more likely (or they happen more often) when the prey is in a more "sensitive" situation (public offerings, starting of a new business, etc.). This is because, other things being equal, the risk (and cost) of adverse publicity is highest (for preys) while, the risk (and cost) that badmouthing be discovered is reduced (for predators). ${ }^{52}$

revenue from stock options is linked to price performance, stock options committed journalists to deliver. However, results did not relate directly to a single journalist's behavior unlike the mechanism we describe.

${ }^{51}$ There is a connection between this and Diego Gambetta's analysis of the mafia as providing protection services on lemons' type of market; see Gambetta, Sicilian Mafia. Likewise, the role of the time horizon in limiting predation in our analysis has resemblance with classic models such as Olson's "Stationary Bandit"; and Olson and McGuire, "Economics of Autocracy." See Olson, Power and Prosperity.

${ }^{52}$ This means that not only bad newspapers but also reliable ones have a greater incentive to provide adverse coverage. See, for instance, Bolton, Freixas, and Shapiro, "Ratings Game." 
In summary, we argue that informal press institutions contained badmouthing within limits that protected the financial market's operation. While we recognize that each of the four predictions we made are consistent with a number of possible theories, we believe that their joint validity is supportive evidence for our analytical narrative.

\section{EVIDENCE: HOW WAS BADMOUTHING SUBDUED}

\section{Reputable Newspapers Live Longer and Charge Readers}

To measure quality, we focus on price. This is consistent with modern signaling theory. ${ }^{53}$ Contemporary observers found that the " 8 or 9 " more serious finance papers were "expensive" because they were produced by "well-known and competent economists whose talent is expensive." 54 Journals boasted the names of competent writers. Thus, the relation we expect is between a journal's time horizon and its price.

Time horizon is measured as incidence rate (share of years when a paper appeared at least once). The data come from the 242 financial publications listed under "finance" in the 1904 edition of the Annuaire de la presse. ${ }^{55}$ That year was near the middle of the period when the number of newspapers was greatest. For each paper published in 1904, we collected price per issue and years since initial publication. We chose price per issue because subscription rates are not comparable across newspapers. We standardized revenue per customer to its weekly value because most newspapers in this group were weekly. Practically, we multiplied the prices of dailies by six (the number of publication days per week), the prices of the fortnightly were divided by two, and so on; 124 newspapers did not have proper prices and so were excluded, leaving

\footnotetext{
${ }^{53}$ Our result is robust to other measures of quality. While circulation is not a feasible measure (circulation was not properly documented at the time, in particular no reliable circulation figures existed for commerce and finance papers) indirect checks exist. As shown later, Raffalovich's choice of reliables shows a preference for pricey journals (Figure 4). Another measure is the thickness of the newspaper. We saw that ghost journals were four-page sheet and cost little. For example, in 1909, La bourse pour tous, obviously a ghost, did cost 10 cents. For a similar format, L'économiste français (perhaps the market leader for quality) had between 36 and 40 pages and did cost 90 cents. We are entirely confident that a systematic cross section of price and volume of content would yield the expected result.

${ }^{54}$ Lajeune-Vilar (Les coulisses, p. 51). Lajeune-Vilar mentions Le messager de Paris, L'économiste français, and Le capitaliste as reliables. On cheap unreliable newspapers, see Moron, Journaux financiers à bon marché; and Soreph, Défends ton argent, p. 54.

${ }^{55}$ D'Avenel, Annuaire. For simplicity, we limited ourselves to newspapers listed under "finance" (thus leaving aside the smaller "political economy") as it includes the vast majority of finance and economic newspapers.
} 
118 newspapers in our sample. ${ }^{56}$ Interestingly, we found newspapers for which there is no price information to be more ephemeral. ${ }^{57}$ This suggests that these were mostly zombies, so that including them in the analysis as "free" newspapers would only strengthen results.

The period during which each journal was around was computed as follows: ${ }^{58}$ For each title of the 770 different newspapers in operation for at least one year between 1890 and 1914, we created an entry. Date of creation was collected as reported by the source. For 108 newspapers, date of creation was not reported. For those, we used instead the first year of appearance of the paper in the Annuaire. ${ }^{59}$ Construction of this data is painstaking because zombies tended to disappear and reappear. Moreover, they often counterfeited the title of a reliable paper. ${ }^{60}$ But once this is done, computation of incidence rates is straightforward. The denominator is the number of years at risk which is at most 17 (the sampled years between 1890 and 1914) but is less for a paper founded after 1890 (14 for a paper created 1895). Newspapers were then sorted by incidence categories (those appearing in 20 percent of the years, those appearing during 20-40 percent of the years, and so on).

Looking at numbers of newspapers in each category, it is clear that there was an army of less reliable newspapers, each with little credibility and no concern about retaining it, and a much narrower group of longerlived, expensive newspapers. The sheer proportion of more occasional titles is striking: 86 percent of all newspapers had an incidence rate lower than 80 percent. ${ }^{61}$ In the 1904 cross section, there are only 8 newspapers in the high-longevity group (in operation during 80-100 percent of the time) against 49 in $0-20$ percent category and 61 in the $20-80$ percent category. This is consistent with our argument that France's financial press mostly comprised vehicles for racketeering.

\footnotetext{
${ }^{56}$ Two newspapers have a price well above the others' (at 3 and 4 francs per issue), which may be a typo. In order not to bias the computation, they are excluded from the sample.

${ }^{57}$ The average lifetime of no price newspapers was significantly shorter than the average population. The hypothesis of equality of average life for price and no-price newspapers is rejected at 5 percent ( $t$-stat of 3.298).

${ }^{58}$ We examined 1890, 1892, 1894, 1895, 1896, 1897, 1898, 1899, 1900, 1901, 1904/05, 1907, 1908, 1910, 1911, 1912, and 1914.

${ }^{59}$ For each year examined and each paper entry, we reported 1 or 0 depending on whether it was published or not.

${ }^{60}$ For instance, La semaine économique et financière (the zombie mentioned in Section I) resembled La semaine financière, a leading reliable paper.

${ }^{61}$ Comparison with London underscores the difference between the two places shown in Figure 1: there only 66 percent of newspapers had an incidence rate lower than 80 percent in the same year.
} 


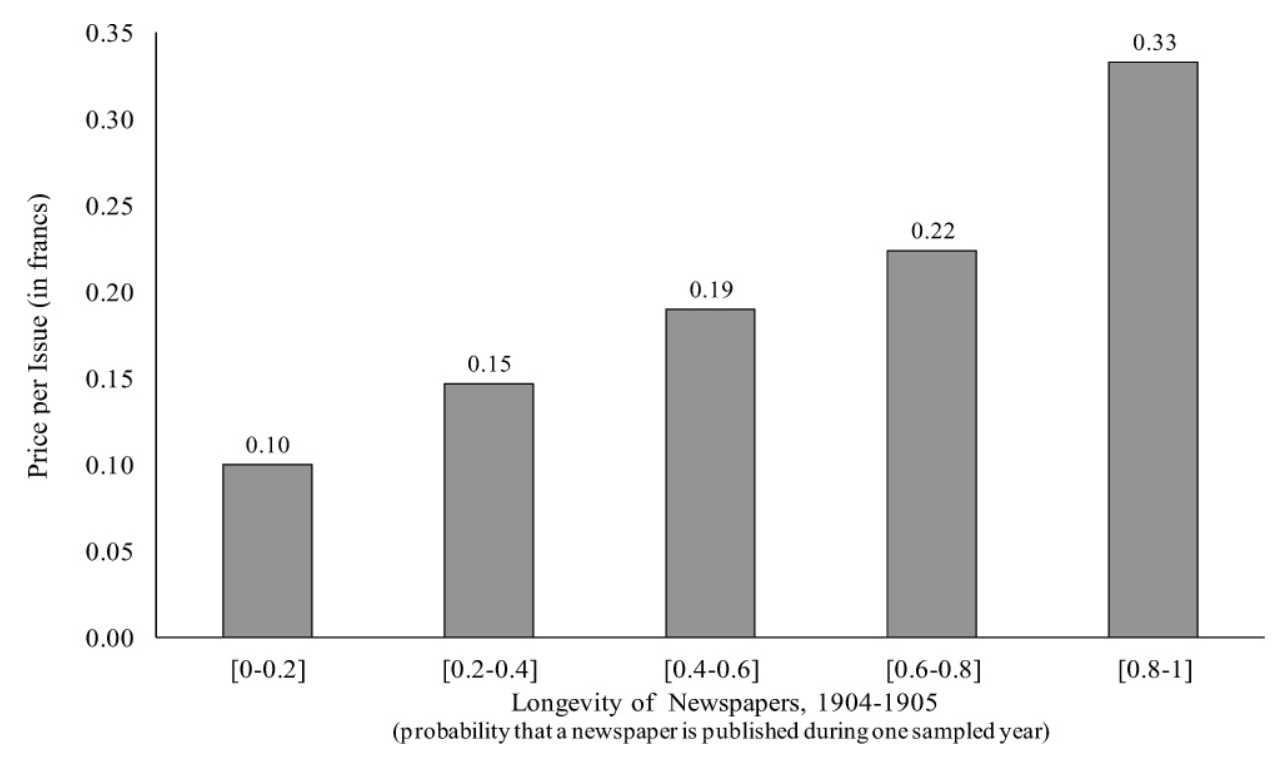

FIGURE 2

PRICE AND TIME HORIZON

Source: Authors' computations, from Mermet, Annuaire de la Presse. See the text.

The price data was then matched with the incidence rates thus constructed. Figure 2 shows the average price per incidence group and it shows that incidence is related to price. Short-lived newspapers (in operation during less than 20 percent of the years) sold, on average, for about 0.10 French francs each; whereas long-lived newspapers (in operation $80-100$ percent of the years) sold for an average price that was three times as high. This evidence supports the view that a newspaper's time horizon and its quality match one another. ${ }^{62}$

\section{Reputable Newspapers Attract More Publicity}

We now move one step further and show that reliable papers were not only able to charge readers, but also to attract more income from

\footnotetext{
${ }^{62}$ Results are robust to changes in benchmark years. For instance, we experienced with previous years such as 1899 or 1900 and found similar results. In the later part of the period (in 1907 or 1912 for example), however, the average price of the ephemeral or newly created newspapers (those in the 0-20 percent category) increased. This is consistent with the fact that contemporaries had been warning consumers to beware of cheap newspapers (for example, Soreph, Défends ton argent, p. 55). In turn, directors of zombies posted higher prices. In a world where price signals quality, even newspapers that are not actually sold have an incentive to post prices similar to those of good newspapers. It seems this practice became more prevalent over time.
} 
publicity. Empirically, the hypothesis we want to test is whether there is a positive correlation between price (an indicator of quality) and gross advertising revenues, meaning that good newspapers can extract more revenues from both ends. Estimating advertising revenues is not easy, because financial newspapers did not generally publish accounts and have left no archives. Using contemporary opinion, we selected eight financial newspapers "representative" of different quality grades. ${ }^{63}$ Next, we picked 1909, a year when complete collections of each of these newspapers could be found in libraries providing knowledge of price-per-issue details and advertising schedules. ${ }^{64}$ Then, we measured the actual number of lines of advertising for each publication date during the first half of 1909 . We included all kinds of advertisement: among others, lists of serial numbers of bonds drawn for reimbursement, as well as minutes of the meetings by shareholders of joint stock banks and nonfinancial companies. ${ }^{65}$ Because advertisement was bought at a fixed price per line, gross revenues are simply the number of lines multiplied by the price of advertising. ${ }^{66}$

We now look at the correlation between price and advertising revenues (Figure 3). The result suggests that reliable papers (measured by price), which we know had the greatest longevity, also attracted more advertising revenues. We see that L'économiste français, France's renowned finance and economics weekly modeled after London's The Economist, sold at the highest price (a price comparable, at market exchange rates, to that of The Economist) and was also the one that collected the most advertising income. ${ }^{67}$ This result was achieved because $L$ 'économiste francais charged on average a price per line 10 percent higher than the median and published 300 percent more lines of advertisement than its median competitor.

Thus the threat of badmouthing leads potential targets to support the high-quality press: it made sense to advertise in good newspapers

\footnotetext{
${ }^{63}$ Six newspapers belonged to the Annuaire's "finance" category, and the other two (Economiste français and Economiste européen) were listed under "économie politique."

${ }^{64}$ The time cost of such measurement limited us to a few newspapers in a single year. It seems, however, that relative amounts of advertising were stable over time, in which case focusing on one year only still captures relative rankings.

${ }^{65} \mathrm{An}$ interesting qualitative take away from it is that bank material, securities offerings, and drawings represented the overwhelming majority of publicity.

${ }^{66}$ One limitation of this approach is that it may overestimate true revenues (since discounts could be granted to large purchasers of ads). However, we suspect that this problem is limited.

${ }^{67}$ L'économiste français also seems to have been profitable, it was listed. The Cote Desfossés shows that it distributed hefty dividends (for example, 180,000 francs in 1909, 200,000 in 1910, 180,000 in 1911, and 280,000 in 1912). The dividend to paid-in capital ratio fluctuated between 12 and 20 percent during the period.
} 


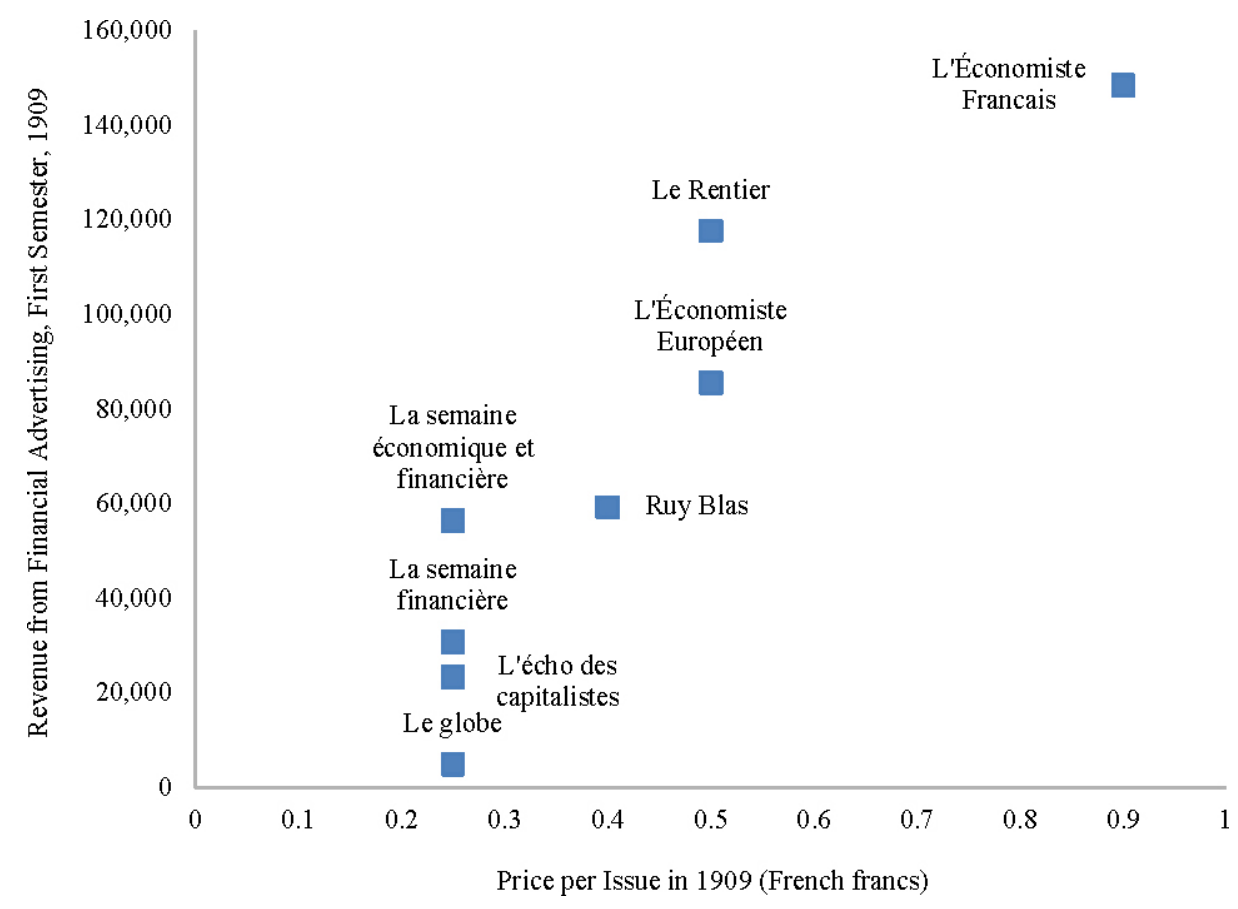

FIGURE 3

ADVERTISING REVENUES AND QUALITY

(price per issue, selected newspapers)

Source: Authors' estimates, from journals. See Appendix online at http://ssrn.com/abstract=1667521.

not only because they were credible, but also because doing so encouraged them to behave properly. The Raffalovich correspondence is consistent with this interpretation. The Russian agent explained that he strongly favored building relationship with the more reputable outlets, including regularly advertising as insurance against a rainy day. $\mathrm{He}$ argued that payments to zombies had to be fiercely contained as they only generated more racketeering and because it was difficult to have a grip on the behavior of bad newspapers after bribes had been paid. Checking Raffalovich's list of "bribed" weekly and quasi-weekly (e.g., published every 10 days) newspapers against information on price (financial press), we find that the Russian government liked the most expensive ones (Figure 4). The average price of financial newspapers was 24.7 centimes in 1905 . The average price of those Raffalovich chose to bribe was 69 centimes. Papers not chosen by Raffalovich came in at 22 centimes. (Numbers are computed by 


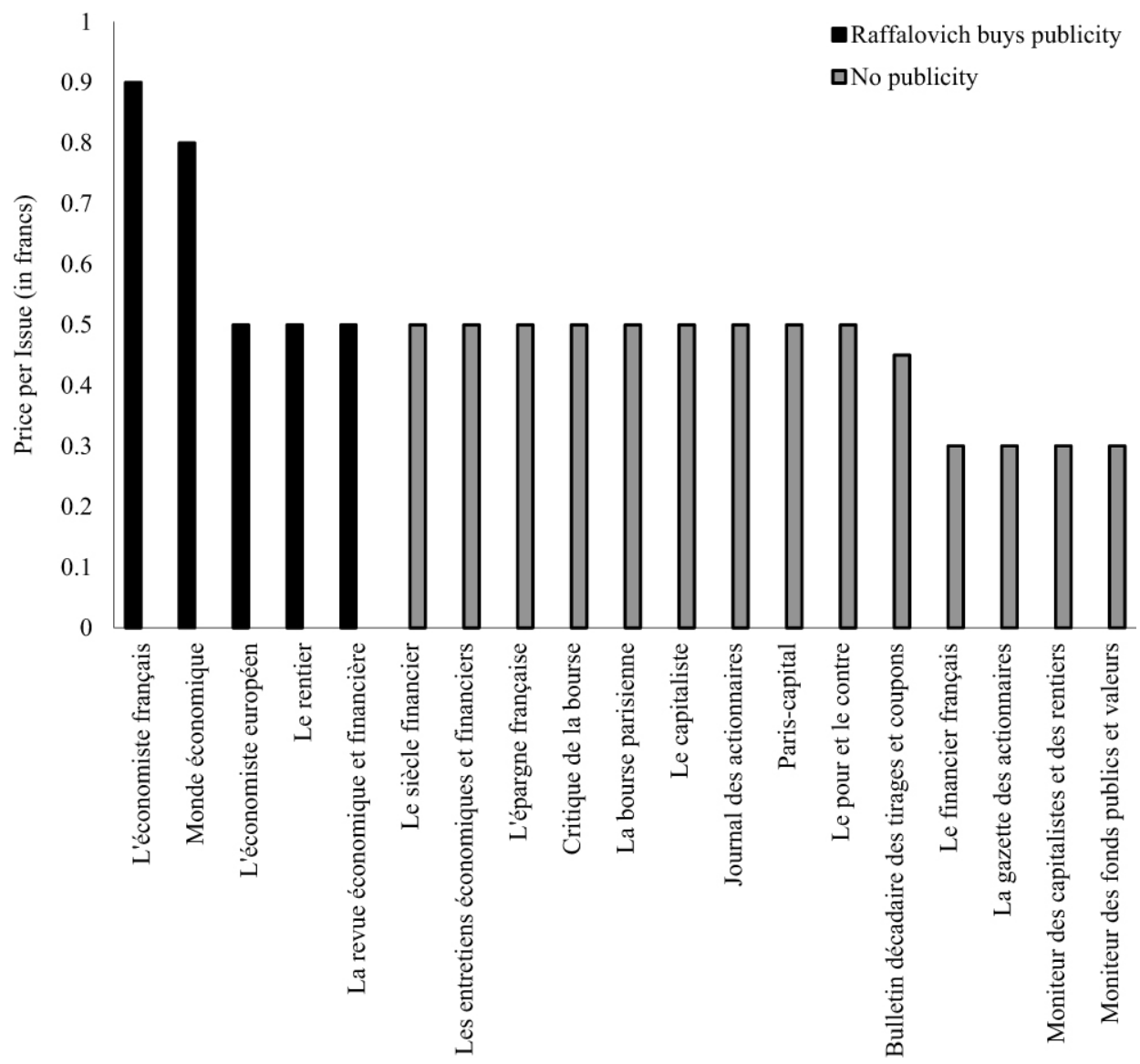

FIGURE 4

ARTHUR'S CHOICE: QUALITY RANKING OF FINANCIAL JOURNALS (ACCORDING TO PRICE PER ISSUE) AND EVIDENCE OF RUSSIAN PURCHASES OF PUBLICITY

Source: Authors, from Raffalovich, L'abominable vénalité; and D'Avenel, Annuaire 1904-05. The 142 weekly and quasi-weekly journals without price per issue and those costing less than 30 cents are not reported. Of these, only La semaine financière, a serious weekly, received publicity from Raffalovich. It cost 25 cents.

adjusting for periodicity and excluding L'avant bourse, a daily digest that was the only no price paper in his list). Similarly, information on circulation (partially available for the general political press) shows Russian agents' preference for established newspapers. ${ }^{68}$ Some historians have described this general pattern (that good newspapers too

${ }^{68}$ On average the 14 general interest newspapers sponsored by Raffalovich sold 291,000 issues a day while the 58 others only sold 18,000 copies. Excluding the four biggest dailies, the average circulation of Raffalovich's sponsored newspapers was twice as high as those he did use. Circulation data are from Albert, "La presse française," p. 296 and evidence on payments is from Raffalovich, L'abominable vénalité. 
received Russian money) as indicating a general "corruption" of French medias. ${ }^{69}$ Our analysis suggests a different, less pessimistic, conclusion. Indeed the facts are consistent with the "issuer pays" model that currently prevails in the rating industry. In particular, it may be efficient (from the target's point of view) to help promote a high-quality press because it acts as a barrier against badmouthing threats of low-quality newspapers. Moreover, a large and competitive high-quality press is also the best way to ensure that the certification business remains contestable.

\section{Publicity Brokers as Delegated Monitors}

Did "dealers in financial advertising" mitigate problems of asymmetric information, monitoring, and enforcement? They certainly had the required knowledge of the market for newspapers and could "price" each rumor and rumor monger. We further argued that the dealers should be big players who aggregate smaller claims and use their market power and longevity to implement retaliation. These claims can be examined despite the fragmentary evidence available.

A contemporary source reckons there were 19 dealers in financial advertising in $1909 .{ }^{70}$ Scattered secondhand accounts give a consistent picture of their relative size. ${ }^{71}$ The main brokers were well known. Observers concurred press brokers were remarkably concentrated and in this respect similar to mafia "bosses." Oscar Marinitsch and LajeuneVilar argue that, in the early 1890s three "godfathers" (Lafon, Batiau \& Privat, and Lenoir) controlled the market. ${ }^{72}$ A decade later, Lysis makes the same claim about three principal brokers cornering the market, adding that the organization of press brokers was "very centralized." Even in the 1930s Henri Loustalan distinguishes only "three or four" leading dealers in financial advertising from more general advertising brokers who were in charge of managing financial advertising for the account of a few newspapers. ${ }^{73}$ It also seems that these patterns were

${ }^{69}$ Jeanneney, "La vénalité."

${ }^{70}$ Favre, Banques et banquiers, p. 82.

${ }^{71}$ Marinitsch, La bourse, pp. 292-96; Lajeune-Vilar, Les coulisses, pp. 54ff; and Lysis, Contre l'oligarchie, pp. 162-63. According to Lajeune-Vilar (Les coulisses, pp. 54ff), the House of Rothschild (an investment bank) and Comptoir d'Escompte (a leading commercial bank) were in business with Lafon. Crédit Lyonnais and the Crédit Foncier (France's biggest commercial bank and main mortgage bank, respectively, the latter involved in the Panama scandal) used Batiau, and Lenoir serviced the French government.

${ }_{72}$ Marinitsch, La bourse; and Lajeune-Vilar, Les coulisses.

${ }^{73}$ To him, this explains the difference between the numbers of dealers in financial advertising found in the various annuaires and the few people that occupy a mafia boss type of position (in Loustalan, La publicité, p. 86). 
remarkably persistent: in the 1890s Lajeune-Vilar reports that Lenoir was the agent for the French government, and ten years later, the Raffalovich briefs show an official from the Ministry of Finance describing Lenoir as "their" agent. ${ }^{74}$

Evidence on how publicity brokerage worked reinforces the notion that they were an instrument for monitoring. Contemporaries suggest that individual targets or preys delegated to their bank the distribution of monies and the banks in turn dealt with a small number of publicity brokers to get the job done. ${ }^{75}$ At the top of the pyramid, the leading press brokers enjoyed considerable power and prestige. This explains Lysis' description of publicity brokers as quasi-officials, on a first name basis with chairmen of leading financial institutions and politicians. ${ }^{76}$

Lack of direct evidence makes it difficult to go beyond the conclusion that concentration gave the publicity brokers powerful retaliatory powers. We have not found any "smoking gun" of direct retaliation. There is plenty of secondhand evidence, however, that suggests that retaliation was the main instrument of enforcement. ${ }^{77}$ The behavior of the largest borrowers provides additional support for this view. Indeed the largest borrowers were also those with the greatest incentives to develop their own monitoring schemes, since they could more easily amortize the cost of acquiring needed expertise because they used the market many times. In other words, they could and should have been able to substitute to brokers. ${ }^{78}$ This was clearly the case of the Russian government which, although it did work with publicity brokers,

\footnotetext{
${ }^{74}$ Lajeune-Vilar, Les coulisses, pp. 54ff; and Raffalovich, L'abominable vénalité, p. 90.

${ }^{75}$ Lysis, Contre l'oligarchie, pp. 168-69: "On financial matters, two or three persons [...] monopolize [the bribery of the press]"; Loustalan, La publicité, p. 86 : "The issuing banks are in Paris in relation with dealers in financial advertising. They are not numerous ( 3 to 4 on the market)."

76 "Publicity brokers are not poor shameful agents working in the shadow, they are officials, they are treated well, they receive distinctions, they represent a social function. These agents of corruption have close links with ministers, they have access to their office. The government gives them awards and medals. [...] Some time ago a press corruptor offered game for lunch to his friends in a chateau. He had the most distinguished guests. On the table were Mr. the Minister of Finance, Mr. the Governor of the Bank of France, Mr. the Governor of the Crédit Foncier, administrators of credit institutions, etc. In summary, the highest names from the financial who's who came to his invitation." Lysis, Contre l'oligarchie, pp. 162-63.

${ }^{77}$ See, for instance, the discussion in Leroy-Beaulieu, L'art, p. 254, which refers to the use of "rental" payments, spread over fairly long time periods, and which must have facilitated punishment and monitoring.

${ }^{78}$ Lajeune-Vilar, (Les coulisses, p. 54) suggests that the existence of intermediaries enabled preys to deal with their racketeers at arm's length. Brokers also freed the prey from the "predictable and unavoidable complaints" of newspapers, some of which had political connections that borrowers did not want to damage. By dealing with a press broker, individual targets and banks were able to filter newspapers' attempts at extracting revenue toward brokers, thereby saving valuable managers' time and avoiding risks of loss of face. The Russian government, by contrast, may have wanted to limit their interaction with politically connected publicity brokers.
} 
took advantage of its regular presence in the Paris market to develop its own approach to monitoring and retaliation. The Raffalovich letters thus provide valuable insights on what brokers were doing (he essentially did the same thing as the brokers). A standard arrangement was to make payments (for publication of such things as results of the drawings of bonds for amortization) conditional upon "proper behavior." As Raffalovich explains: "It must be understood that [payment] will last 'during good behavior' because if they cheat too openly on us, the minister can always become angry." 79 There are cases when the minister or Raffalovich actually got angry and discontinued payments. ${ }^{80}$

\section{Vulnerability and Bribes: Public Offerings and Badmouthing}

In the previous section, we suggested that there should be a connection between badmouthing and public offerings. This implies that, the larger the offering, the greater the opportunities for zombies-a kind of predator-prey relation. This notion is supported by abundant contemporary statements. Lajeune-Vilar mentions the connection and other writers brought it up repeatedly afterwards. ${ }^{81}$ Alfred Neymarck, an economist and the director of a leading financial newspaper (Le rentier), describes the promotion of public offerings in newspapers through advertisements, paid articles, and distribution of stock options as part of the normal process "in France and abroad." ${ }^{\circ 2}$ Lysis gives examples: the Bank of France increased its payments ("rations") when its charter had to be renewed; Banks made payments every time they placed a security in the public. Paul Leroy-Beaulieu (the editor of L'économiste français) also explains that security issues were always associated with payments to the press. A 1909 article in Le globe goes further and gives details about specific schemes. ${ }^{83}$

Contemporary insiders and critics thus agree with our prediction that vulnerability should be associated with securities offerings. Some data can be used to confirm this. The hypothesis is that free entry in the badmouthing trade combined with the absence of fixed costs in organizing rackets implies that the volume of potential targets (measured by the volume of securities offerings on the market)

\footnotetext{
${ }^{79}$ Raffalovich, L'abominable vénalité, p. 187.

${ }^{80}$ Ibid., p. 197; Actual retaliation occurred against Le messager de Paris and La patrie in 1908.

${ }^{81}$ Lajeune-Vilar, Les coulisses, pp. 33-34.

${ }^{82}$ Neymarck, Finances contemporaines, pp. 63-64, 66.

${ }^{83}$ Lysis, Contre l'oligarchie, pp. 168-69; Leroy-Beaulieu, L'art, pp. 251-54; and Le globe, 11 November 1909, 858.
} 


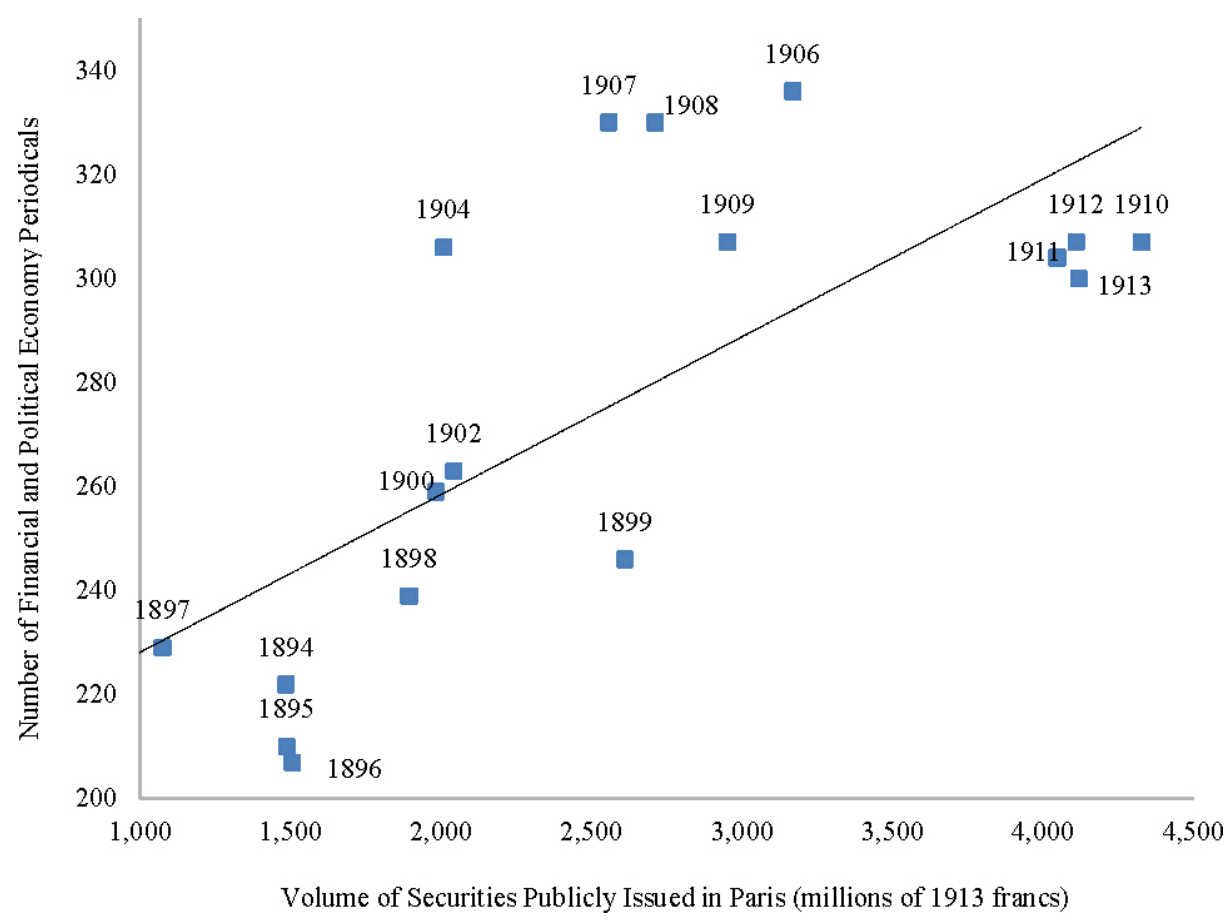

\author{
FIGURE 5 \\ NUMBER OF FINANCIAL AND POLITICAL ECONOMY JOURNALS AND IPO \\ VOLUMES IN PARIS \\ $(1892-1913)$
}

Source: Newspapers: Authors. Securities publicly issued in Paris from Saul ("Banking Alliances," p. 122, stock publicly issued in France) citing Chadeau, L'économie nationale au 19 ème siècle) and the INSEE statistical yearbook (1951, 1961, and 1966). Nominal values were deflated using the index of Lévy-Leboyer and Bourguignon, L'économie française.

should be positively related to the number of fly-by-night newspapers entering in the Annuaire. Figure 5 plots the number of financial newspapers from the Annuaire against securities offerings values in Paris from 1892 to 1913 deflated with Maurice Lévy-Leboyer and François Bourguignon's price index. ${ }^{84}$ The chart shows the correlation is large and it is significant.

We can perform a finer test by examining if there is a dynamic connection between the two series. Stock market booms provided abundant racketing opportunities: increases in public offerings should have led to increases in the number of bad journals (since badmouthing is competitive). ${ }^{85}$ It would be tempting to establish the correlation

\footnotetext{
${ }^{84}$ Saul, "Banking Alliances"; and Lévy-Leboyer and Bourguignon, L'économie française.

${ }^{85}$ Figure 1 offers just that evidence. We can "read" the footprints of the speculation and crisis
} 
between variation of the volume of offerings and variation of the number of newspapers. One problem with this relation however, is that the Annuaire was not published annually in the early 1900 s, thus we cannot always match variations of number of newspapers in two subsequent Annuaires and the number of securities offerings.

Instead, we explore the dynamic relation between newspapers and public offerings using cointegration methods. The idea of cointegration analysis is to capture a dynamic equilibrium relation between two variables; in our case, the relation which we postulate is between number of newspapers and volumes of securities offered to the public. To do so, however, one must have a sufficiently long series of observations or results will not be significant. The total offerings series we used in Figure 5 (1892-1913) is too short (only 19 observations since we are missing some years when the Annuaire did not appear). We thus use instead Arbulu's stock issues on the official market; it is substantially longer (1881-1913). ${ }^{86}$ Cointegration analysis results are supportive: the number of newspapers and the stock offerings series are cointegrated and positively related. ${ }^{87}$

\section{THE COSTS OF BADMOUTHING}

\section{How Much was Appropriated?}

We now construct estimates of the "overall" revenues that the press (good or bad) derived from securities offerings. Revenues from offerings represent only a fraction of the total amounts issuers paid to the press because as we explained, good newspapers would attract advertising even if there were no new securities. Yet focusing on offerings helps evaluate

associated with the Union Générale scandal of 1881 and the Panama Canal scandal in 1892. On these crises and surrounding speculation, see Simon, Panama Affair; Bouvier, Deux scandales and Le krach; and Kindleberger, Manias, pp. 114-15.

${ }^{86}$ Arbulu, "Le marché parisien."

${ }^{87}$ We follow the method of Engle and Granger, "Co-Integration" and use their two steps method of residuals-based test of cointegration. Both the series of log of the number of newspapers and the log of deflated IPO values are I(1). Regression of newspapers on IPO shows a positive and significant coefficient of the IPO variable ( 0.12 with a $t$-stat of 2.67). If the residual of the regression is stationary, then the inference is that the number of newspapers (in $\log$ ) and the IPO value (in $\log$ ) are cointegrated. As shown by the result of the Elliott, Rothenberg, and Stock ("Efficient Tests") unit root test (with a value of $-2.96<-2.63$ at 1 percent) and of the $\mathrm{Ng}$ and Perron ("Lag Length") test $(-11.4<8.1$ at 5 percent), the residual is stationary. Therefore the number of newspapers and the volume of IPO are cointegrated. Furthermore, the series of IPO volume does Granger-causes the series of financial and political economy newspapers but the reverse causality is not found (Granger, "Investigating"). All the results are unaffected if the variables are taken in absolute numbers. 


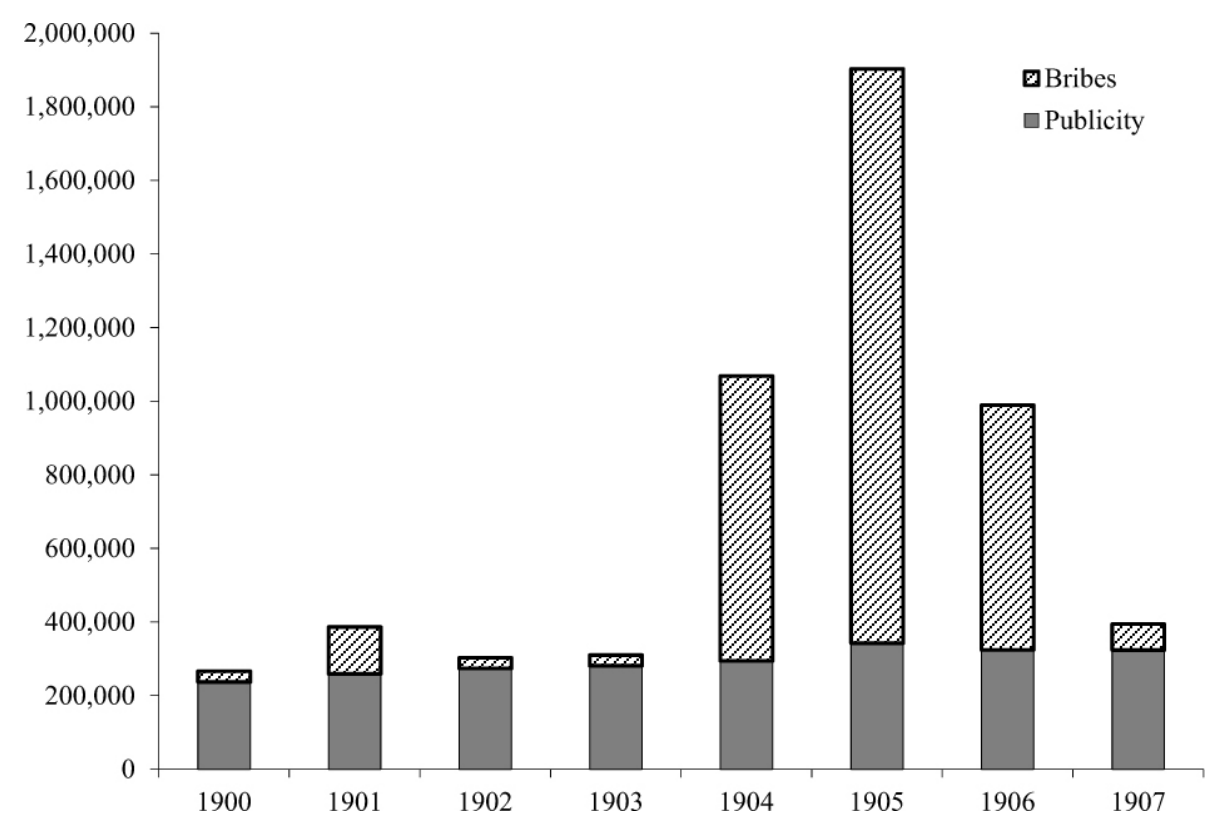

FIGURE 6

RUSSIAN BRIBES AND PUBLICITY DURING THE 1900S (FF)

Source: Authors, from Raffalovich, L'abominable vénalité.

the amount of money that was being "wasted" as it is when we expect zombies to have captured the biggest revenues. Figure 6 shows Russian government's total payments to the press using Raffalovich's own distinction between regular payments ("advertising") and exceptional expenses ("bribes"). The figure is a vivid illustration of the effect we mentioned earlier: while advertising expenses were stable (vindicating its interpretation as an insurance premium) bribes were volatile. And they peaked between 1904 and 1906 (between the outbreak of the war with Japan and the eventual consolidation of Russian finances through a 1906 security issue). Vulnerability prompted the zombie attack.

To construct total offerings-related expenditures on the press, we first estimate the average amount of money paid to the press for a security offering of a given value and then multiply it by the total value of offerings. Contemporary reports suggest that press brokers were paid a lump-sum fee for their service and it is this average fee we need to estimate. ${ }^{88}$ One source is underwriting contracts since they often mention payments "made to the press," but expenses are not reported

\footnotetext{
${ }^{88}$ Lysis, Contre l'oligarchie, pp. 162-63. Incidentally, because of payment as a lump-sum fee brokers lost money if payments to papers overran, and this aligned the broker's incentives with that of the prey.
} 
transparently. ${ }^{89}$ We took advantage of an episode when information on payments to the press for a few loans was divulged by the director general of Banque de Paris et des Pays-Bas (an investment bank) to the newspaper Le globe in $1909 .{ }^{90}$ We then matched the material printed by Le globe with the actual contracts which we retrieved in this bank's archive, yielding high-quality data for three foreign government loans. ${ }^{91}$

Table 1 displays information we organized from both the underwriting contracts and Le globe..$^{2}$ The three loans are a 1899 Crédit Foncier de Hongrie bond (obligations communales 3.5 percent), a 1902 Bulgarian 5 percent loan, and a 1905 Brazilian (Sao Paulo) 5 percent loan. We examine payments to the press relative to the net amount raised by issuers and relative to underwriting fees. Comparison with amounts appropriated by bankers is relevant because beyond financial services (originating, marketing, distributing, and insurance services), they also provided signals of the issue's quality. ${ }^{93}$ Banks "competed" with the press. We also document a 1906 Russian 5 percent loan that concluded the protracted period of "Russia bashing" started with the Russo-Japanese War (1904-1906). In this case, the distribution of monies was not indirectly related to the loan itself because the campaign began long before Russia decided to borrow. One reason for adding this loan is that Russia (unlike the other borrowers of Table 1) mostly dealt with zombies directly: it is informative to see whether large repeat issuers who had some expertise and did not delegate entirely to the press brokers managed to spend less.

\footnotetext{
${ }^{89}$ Sometimes indications are made that publicity expenditures are borne out by the underwriters (that is, paid out of underwriting fees to banks) and no details are given.

${ }^{90}$ Le globe published data for the Hungarian loan on 25 November 1909 (pp. 908-09), for the Bulgarian loan a week later (on 2 December 1909, pp. 930-31), and for the Sao Paulo loan on 9 December 1909 (pp. 948-50). For comment and a discussion of the reasons for the leak, see $L$ 'écho des capitalistes of 9 December 1909. L'écho reported that Albert Turrettini, the new director general of the bank declared, "La presse, je m'en f...!" (in English, "F... the press!").

${ }^{91}$ Banque de Paris et des Pays Bas archives at the BNP-Paribas in Paris. Hungary: folder BPPB 1/CABET 1/13 and BPPB 11/DFOM-221/669; Bulgaria: folder BPPB 6/DFOM-221/61; and Sao Paulo: folder BPPB 11/DFOM-221/424 and 11 DFOM 221/424.

${ }^{92}$ The advertising expenses of the Sao Paulo loan published in Le globe $(210,000 \mathrm{FF})$ require corrections. L'écho des capitalistes (9 December 1909) pointed the incompleteness of the list. The archives of the banking syndicate mention a total of 367,317 FF paid using Lenoir as press broker (folder 11 DFOM 221/424).

${ }^{93}$ Flandreau and Flores, "Bonds and Brands." For details on underwriting fees paid to French banks during the period, see Flandreau et al., "End of Gatekeeping." Their study implies that fees in Britain and France were roughly competitive.
} 
TABLE 1

THE COST OF BADMOUTHING: VALUE APPROPRIATED BY INTERMEDIARIES

\begin{tabular}{|c|c|c|c|c|}
\hline & $\begin{array}{c}\text { Hungarian } \\
\text { Mortgage } \\
\text { Bank 3.5\% } \\
1899 \\
\end{array}$ & $\begin{array}{c}\text { Bulgaria 5\% } \\
1902\end{array}$ & $\begin{array}{c}\text { Sao Paulo 5\% } \\
1905\end{array}$ & $\begin{array}{c}\text { Russia 5\% } \\
1906\end{array}$ \\
\hline Date & 1899 & 1902 & 1905 & 1904-1906 \\
\hline Amount raised by borrower (M FF) (a) & 17.75 & 86.40 & 34.98 (b) & $1002.00(\mathrm{~b})$ \\
\hline \multicolumn{5}{|l|}{ "Bribes" } \\
\hline Amount (M FF) & na & na & na & $5.00(\mathrm{c})$ \\
\hline Percent of amount raised & na & na & na & 0.50 \\
\hline \multicolumn{5}{|l|}{ "Bribes" and "Publicity" } \\
\hline Amount (M FF) & 0.09 & 0.43 & 0.37 & 6.00 \\
\hline Percent of amount raised & 0.53 & 0.50 & $1.05(\mathrm{~d})$ & 0.60 \\
\hline \multicolumn{5}{|l|}{ Bankers' fee } \\
\hline Amount (M FF) & 0.65 & 7.42 & 2.10 & 54.00 \\
\hline Percent of amount raised & 4.25 & 8.59 & 6.01 & 5.30 \\
\hline Press as percent of Bankers' fee & 14.54 & 5.8 & 17.59 & 11.00 \\
\hline
\end{tabular}

(a) Value of issue net of Bankers' fees, and stamp duty (not reported).

(b) Paris share.

(c) Three million for bribes between February 1904 and June 1906 (from Raffalovich, L'abominable vénalité), plus 2 million for advertising (from contract with the Russian government, dated April 16, 1906, Crédit Lyonnais archive).

(d) The loan was issued by an international syndicate. The percentage reported is for Paribas' 40 percent share of the whole issue that was placed in Paris.

Sources: Le globe, November 251909 (Hungary), December 21909 (Bulgaria), December 9 1909 (Sao Paulo); BNP Paribas archives (BPPB), 1/CABET 1/13 and BPPB 11/DFOM-221/669 (Hungary), BPPB 6/DFOM-221/61 (Bulgaria), BPPB 11/DFOM-221/424 (Sao Paulo), Raffalovich (L'abominable vénalité, Russia), Suzuki (Japanese Government Loan Issues); Archive Crédit Lyonnais, Emprunt Russe 5 percent 1906, Schedule no 29.336. BPPB 5/DFOM$221 / 21$

Three features stand out. First, as a share of the capital actually borrowed, the amounts appropriated are relatively small: about half of a percentage point. Second, they also only represent 6 to 18 percent of underwriting fees. Most of the value resulting from certification services seems to have been appropriated by banks, not by the media. ${ }^{94}$ With the help of the press brokers, large banks must have disciplined badmouthing. Had it been unchecked, badmouthing would have eaten into banks' margins and risked jeopardizing international competitiveness (thus the Banque de Paris et des Pays-Bas' director general loss of patience as he did?)

The numbers for Russia are also interesting. Although the campaign was spread out over two and a half years, the total spent (relative to the

\footnotetext{
${ }^{94}$ Payments to the press were relatively large compared with modern underwriting fees for similar securities, which averaged 0.54 percent for issues in New York from 1993 to 2007; see Flandreau et al., "End of Gatekeeping."
} 


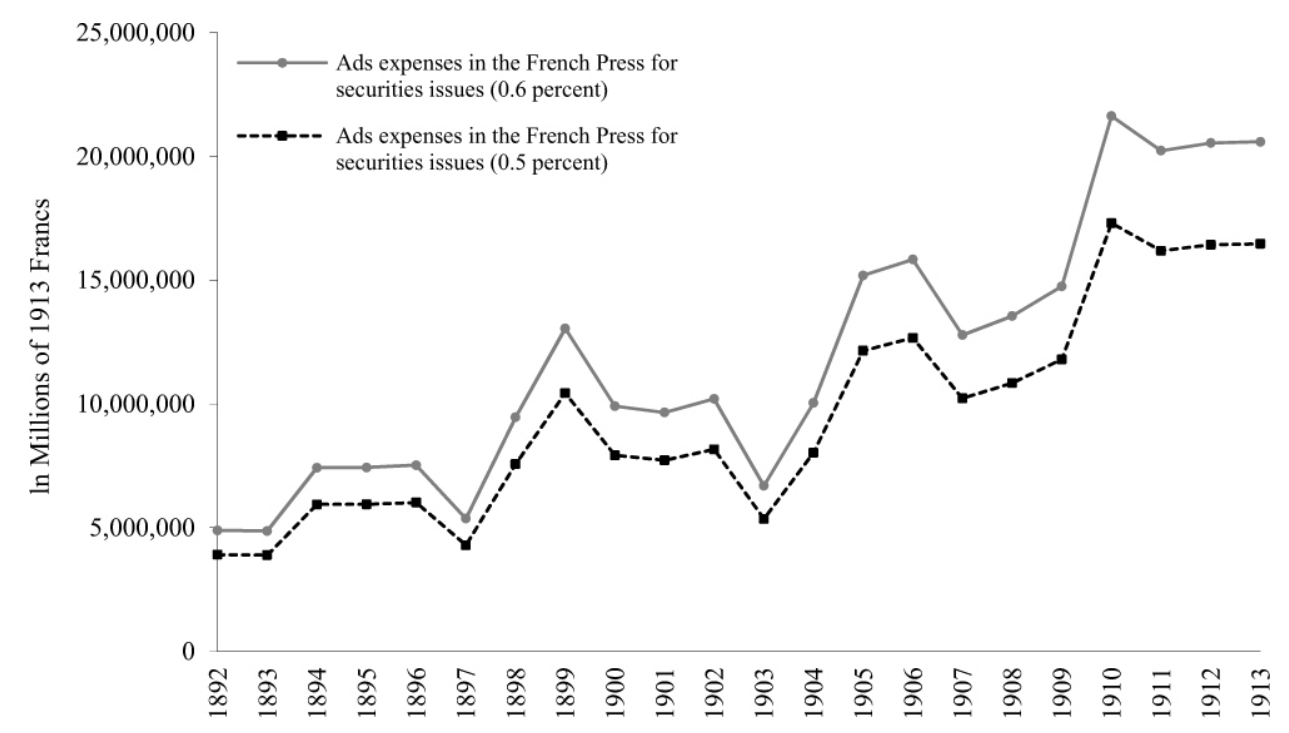

FIGURE 7

IPO ADVERTISING EXPENSES FOR ISSUES IN PARIS

Source: Securities publicly issued in Paris from Saul ("Banking Alliances," p. 122, series stock publicly issued in France). The nominal values were deflated using the price index of LévyLeboyer and Bourguignon, $L$ 'économie française.

value of the 1906 loan) is comparable to what we find for other deals where monies were paid in relation to one issue only. Russia's campaign was cost effective: bigger agents who were better equipped to handle racketeers faced lower costs. It also explains why Raffalovich often advocated circumventing the publicity brokers.

Finally, multiplying our estimates of issue-related payments with the volumes of security issues enables to assess the total amounts appropriated by the press (Figure 7). Table 1 gives appropriations between 0.5 percent and 0.6 percent of amounts received by borrowers. This represents about 0.4 to 0.5 percent of the price paid by the public (the public offering). ${ }^{95}$ In constant 1913 francs, annual issue-related payments ranged between 10 million FF (early 1900s) and about 20 million FF (1913). ${ }^{96}$ These are large absolute numbers; they are large when compared with what the Crédit Lyonnais (a leading underwriter) spent annually on its 100 employees research department (around 1900, 1 million FF). ${ }^{97}$

\footnotetext{
${ }^{95}$ Sao Paulo issue left aside (1.05 percent of amount raised by borrower). The loan was issued jointly by Paribas and Dresdner Bank. The strong anti-German stance in France may have caused the high fee.

${ }^{96}$ The amount paid to the press sums up between 209 and 261 million of 1913 FF (between 0.65 or 0.82 billion of 2009 euros).

${ }^{97}$ Flandreau, "Caveat Emptor."
} 
TABLE 2

PAYMENTS TO RELIABLE NEWSPAPERS DURING THREE LOAN ISSUES

\begin{tabular}{|c|c|c|c|}
\hline $\begin{array}{l}\text { Share distributed to brokers and influential periodicals } \\
\text { (in percentage of the advertising budget) }\end{array}$ & $\begin{array}{c}\text { Hungarian } \\
\text { Mortgage } \\
\text { Bank } \\
3.5 \% 1899\end{array}$ & $\begin{array}{r}\text { Bulgaria } \\
5 \% 1902\end{array}$ & $\begin{array}{l}\text { Sao Paulo } \\
5 \% 1905\end{array}$ \\
\hline Underworld (any other papers and publicity brokers) ${ }^{\mathrm{a}}$ & 70.64 & 65.74 & 62.74 \\
\hline Quality (total influential papers, financial and general) & 29.36 & 34.26 & 38.26 \\
\hline Of which & & & \\
\hline Influential political or general interest newspapers ${ }^{b}$ & 24.33 & 30.41 & 29.41 \\
\hline $\begin{array}{l}\text { Among which, those with a circulation greater } \\
\text { than } 50,000 \text { a day }\end{array}$ & 16.4 & 17.25 & 19.81 \\
\hline $\begin{array}{l}\text { Among which, those with a circulation lower than } \\
50,000 \text { a day }\end{array}$ & 7.93 & 13.16 & 9.6 \\
\hline Influential financial periodicals & 5.03 & 3.85 & 8.85 \\
\hline Total & 100 & 100 & 100 \\
\hline
\end{tabular}

\section{Value Diversion by Zombies}

The information leaked by the disgruntled director of Paribas included a list of newspapers and intermediaries that were paid. We subtracted from expenses to the press what was distributed to "reliable" papers; the residual includes bribes to bad newspapers and press brokers' commissions. ${ }^{98}$ Reliable papers were identified using Raffalovich's list of serious financial and general interest newspapers. ${ }^{99}$ In Table 2, they are respectively identified as "influential financial newspapers" and "influential general newspapers." The table then shows that between 62 percent and 70 percent of the press budget went to zombies and brokers. ${ }^{100}$

It is striking that although reliable papers did attract resources (through regular advertising payments which are not taken into account in our

\footnotetext{
${ }^{98}$ Lenoir was referred to as "Mr. X." Other brokers who acted for several journals at once were referred to as "Régies."

${ }^{99}$ L'abominable vénalité.

${ }^{100}$ As an alternative to the Raffalovich criterion, we also identify leading general-interest dailies by selecting papers with a circulation greater than 50,000 in 1910 (Albert, "La presse française," p. 296). This category overlaps only partly with the Raffalovich list; five of the twelve papers with circulation of 50,000 or more a day were not paid by the Russians. Likewise, we selected the most expensive financial journals ( $50 \mathrm{cts}$ or more). Computations with this alternative definition do not alter the finding that 60 to 70 percent of monies went to zombies.
} 
securities issue payment schedules), their share barely reached 40 percent of press-related issue expenses. Leading financial newspapers thus received but a small portion, a fact that contemporary observers deplored. ${ }^{101}$ Within the good journals, the main recipients were the generalist newspapers with large circulation. This makes sense because their nonspecialized form enabled them both to reach a wide audience and to apply extensive "soft" badmouthing by ignoring certain issuers. It does give us pause, therefore, that relatively little money went to good research compared to what was thrown after the army of zombies and their mafialike bosses.

\section{CONCLUSIONS}

This article analyzed the market for financial information in France before World War I. We examined how libel law, or a lack thereof, made reputation fragile and encouraged the creation of at least 250 "zombie" finance newspapers, at the turn of the century. Newspapers without a reputation did not hesitate to make damaging allegations. Indirect coordination was assisted by bandwagon effects and/or availability of a meeting point (the Académie de chant). Finally, rumors were more likely to be planted when there was a greater likelihood that others would pick it up and new security offerings provided good opportunities.

Against that, we identified two main mechanisms that mitigated the impact of "zombies." First, more serious papers found their value in insuring securities issuers against the adverse effects of rumors. L'économiste français and other papers emerged as standards of reliability, and they benefited from stable advertising revenues. This finding, we argue, may explain why providers of financial information were able to charge the concerns they "rated"- an issue relevant to the renewed debate over the relations between issuers and rating agencies.

A second solution emerged to deal with badmouthing: coalitions of issuers structured by bankers (the underwriters) and the pooling of bribes through delegated monitors called "publicity brokers." By signing up a number of (financially incompetent) people for press campaigns, the brokers subsidized a "party" supporting the issuers that had paid for it: a badmouthing paper could be paid above its opportunity cost. At that point, information-poor media chose not to fabricate

\footnotetext{
101 "The influential financial newspapers, those that incite the capitalists to buy stocks and bonds offerings, those providing financial advice that are followed by their readers and subscribers appear in this advertising budget for a relatively tiny amount." L'écho des capitalistes (9 December 1909, no 42, 1). Le globe (9 November 1909, 858) pointed out that, "The wealth of investors feeds the cashbox of numerous political newspapers although their advertising is notoriously useless."
} 
damaging information. Second, because of their concentration, brokers had the means to retaliate against deviating low-quality newspapers.

This scenario belonged to the world of second-best solutions. For the "Belle Epoque" as the era leading up to World War I is known, we estimated that roughly 10.5 million 1913 francs were paid annually in "bribes," of which some 60 percent ended up in the pockets of racketeers. Although this may have been small potatoes compared to total issues in Paris or to the benefits that accrued to underwriters, an average of 235 million 1913 francs paid out during the 1892-1913 period is large. In a better world, this money-instead of lining the pockets of white-collar racketeers - could have funded a higher-quality press. It did not. This was regretted by many, including the Russian financial agent Raffalovich. ${ }^{102}$ Why was it so? This is a topic for future research. We note that the situation did benefit the brokers, the bad journals, but also various brands of incumbents in politics and banking: they may have found it in their interest to maintain a critical level of badmouthing as an informational friction on which they could prey.

It may well be that certification by newspapers (or rating agencies) competes against certification by banks. Recent research shows that during this period, underwriting banks collected large revenues from underwriting and certification services. ${ }^{103} \mathrm{~A}$ higher-quality press might well have reduced the profit margins of investment banks. Bankers may thus have preferred to bribe journals, and-by sustaining enough corruption - they depreciated the quality of their competitor's certification which amounted to protecting their own - and corresponding revenues.

Yet there are other elements to this problem including the role of politicians. As has been argued before, politicians and parties were generally involved in the information racket. Politicians appeared at both ends of the game: the executive branch purchased press coverage for domestic loans while individual politicians could raise funds by running their own zombie papers because they could complicate life for targets. Newspapers, some of which were controlled by political parties, were ideal vehicles for laundering racket money, because whatever the end purpose bribes could be simply registered under "publicity." In short, certification business could have been captured by special interests and to some extent it was. Ironically, a regime based on freedom of speech does not guarantee that the truth will come out.

\footnotetext{
102 Raffalovich, L'abominable vénalité.

${ }^{103}$ Flandreau et al., "End of Gatekeeping."
} 


\section{REFERENCES}

Ageron, Charles Robert. "La vénalité de la presse française dans la première moitié du XXe siècle. L'action des États étrangers." Cahiers de l'Institut d'Histoire de la Presse et de l'Opinion $\mathrm{n}^{\circ} 3$, Tours (1975): 107-30.

Akerlof, George A. "The Market for 'Lemons': Quality Uncertainty and the Market Mechanism." The Quarterly Journal of Economics 84, no. 3 (1970): 488-500.

Albert, Pierre. "La presse française de 1871 à 1940." In Histoire générale de la presse française, tome III, edited by Claude Bellanger, Jacques Godechot, Pierre Guiral, and Fernand Terrou, Paris: PUF, 1972.

Anno Sexto \& Septimo. "An Act to Amend the Law Respecting Defamatory Words and Libels." Victoriae Reginae. CAP. XCVI.

Archives de l'Agence Havas, Archives Nationales, Paris.

Archives de la Banque de Paris et des Pays-Bas, Paris.

Archives de la Société Générale, Paris.

Archives du Crédit Agricole (for Crédit Lyonnais Archive), Paris.

Arbulu, Pedro. "Le marché parisien des actions au 19ème siècle." In Le marché financier français au XIXe siècle, Vol. 2, edited by G. Gallais-Hamonno, 365458. Paris: Publications de la Sorbonne, 2007.

Balzac, Honoré de. La maison Nucingen. Paris: Flammarion, 1837.

Bar-Gill, Oren, and Assaf Hamdani. "Optimal Liability for Libel." Contributions to Economic Analysis \& Policy, Berkeley Electronic Press, Vol. 2, (2003): Article 6.

Baron, David P. "Persistent Media Bias." Journal of Public Economics 90, no. 1-2 (2006): 1-36.

Besley, Timothy, and Andrea Prat. "Handcuffs for the Grabbing Hand? Media Capture and Government Accountability." American Economic Review 96, no. 3 (2006): 720-36.

Bignon, Vincent, and Antonio Miscio. "Media Bias in Financial Newspapers: Evidence from Early-Twentieth-Century France." European Review of Economic History 14, no. 3 (2010): 383-432.

Bloch, Marc. L'étrange défaite. Paris: Ed. Franc-tireur, 1940 [1946].

Bolton, Patrick, Xavier Freixas, and Joel David Shapiro. "The Credit Ratings Game." EFA, Bergen Meetings Paper, 2009.

Bouvier, Jean. Le krach de l'Union Générale. Paris: PUF, 1960. . Les deux scandales de Panama. Paris: Julliard, 1964.

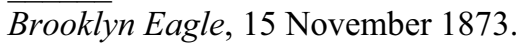

Byoun, Soku, and Yoon S. Shin. "Unsolicited Credit Ratings: Theory and Empirical Analysis." Unpublished Manuscript, 2003.

Cantor, Richard, and Frank Packer. "The Credit Rating Industry." Quarterly Review, Federal Reserve Bank of New York, Summer (1994): 1-26.

Chadeau, Emmanuel. L'économie nationale au 19ème siècle. Paris: Presses de l'Ecole Normale Supérieure, 1989.

Cote Desfossés, Cours authentique et officiel de la Bourse de Paris. Paris, various years.

Dalvi, Manoj, and James F. Refalo. "An Economic Analysis of Libel Law." Eastern Economic Journal 34, no. 1 (2008): 74-94.

D’Avenel, Henri. Annuaire de la presse. Paris: Annuaire de la presse, 1904.

D’Avenel,Vicomte G. "Le mécanisme de la vie moderne. La publicité." Revue des deux mondes, Janvier-Février (1901): 628-59.

Diamond, Douglas W. "Reputation Acquisition in Debt Markets." Journal of Political Economy 97, no. 4 (1989): 828-62. 
Djankov, Simeon, Caralee McLiesch, Nenova Tatiana, and Andrei Shleifer. "Who Owns the Media?" Journal of Law and Economics 46, no. 2 (2003): 341-81.

Duguid, Charles. How to Read the Money Article. Fifth edition, revised. London: Effingham Wilson, 1906.

Dujardin, Édouard. Annuaire du duel, 1880-1889. Paris: Perrin, 1891.

Dyck, Alexander, Natalya Volchkova, and Luigi Zingales. "The Corporate Governance Role of the Media: Evidence from Russia." Journal of Finance 63, no. 3 (2008): 1093-135.

Elliott, Graham, Thomas J. Rothenberg, and James H. Stock. "Efficient Tests for an Autoregressive Unit Root." Econometrica 64, no. 4 (1996): 813-36.

Ellschot, Willem. Lijmen. Amsterdam: Tepas, 1924.

Engle, Robert F., and Clive W. J. Granger. "Co-Integration and Error-Correction: Representation, Estimation, and Testing." Econometrica 55, no. 2 (1987): 251-76.

Favre, J. E. Banques et banquiers de Paris. Paris: Publications Financières Favre, 1909.

Flandreau, Marc. "Caveat Emptor: Coping with Sovereign Risk Under the International Gold Standard." In International Financial History in the Twentieth Century, System and Anarchy, edited by M. Flandreau, C.-L. Holtfrerich, and H. James, 1750. Cambridge: Cambridge University Press, 2003.

Flandreau, Marc, and Juan Flores. "Bonds and Brands: Foundations of Sovereign Debt Markets, 1820-1830." The Journal of Economic History 69, no. 3 (2009):64684.

Flandreau, Marc, Juan Flores, Norbert Gaillard, and Sebastián Nieto-Parra. "The End of Gatekeeping: Underwriters and the Quality of Sovereign Debt Markets, 18152007." NBER International Seminar on Macroeconomics Vol. 6, 2010.

Flandreau, Marc, Norbert Gaillard, and Frank Packer. "To Err is Human: Rating Agencies and the Interwar Foreign Government Debt Crisis.” BIS Working Paper $335,2011$.

Gambetta, Diego. The Sicilian Mafia: The Business of Private Protection. Cambridge, MA: Harvard University Press, 1993.

Garoupa, Nuno. "Dishonesty and Libel Law: The Economics of the 'Chilling' Effect." Journal of Institutional and Theoretical Economics 155, no. 2 (1999): 284-300.

Gébé, Victor. Catalogue des journaux imprimés. Paris: Brunox, 1875, 1877.

Gentzkow, Matthew, Edward L. Glaeser, and Claudia Goldin. "The Rise of the Fourth Estate: How Newspapers Became Informative and Why It Mattered." In Corruption and Reform: Lessons from America's Economic History, edited by E. Glaeser and C. Goldin, 187-230. Chicago: Chicago University Press. Series: NBER Conference Report, 2006.

Gentzkow, Matthew, and James Shapiro. "Media Bias and Reputation." Journal of Political Economy 114, no. 2 (2006): 280-316.

Gorton, Gary. "Reputation Formation in Early Banknotes Markets." Journal of Political Economy 104, no. 2 (1996): 346-97.

Granger, Clive W. J. "Investigating Causal Relations by Econometric Models and Cross-Spectral Methods." Econometrica 37, no. 3 (1969): 424-38.

INSEE statistical yearbook, 1951, 1961, and 1966.

Jeanneney, Jean-Noël. "La vénalité du journalisme financier pendant l'entre deux guerres.” In L'argent caché, chapter 7, edited by J. N. Jeanneney, 205-30. Paris: Points Seuil, 1981.

Kindleberger, Charles P. Manias, Panics, and Crashes: A History of Financial Crises. New York: John Wiley \& Sons, 1996 (third edition, first in 1978). 
Koss, Stephen. The Rise and Fall of the Political Press in Britain, Vol. 1, The Nineteenth Century. London: Hamish Hamilton, 1981.

Lajeune-Vilar, André. Les coulisses de la presse: Mours et chantages du journalisme. Paris: A. Charles, 1895.

L'écho des capitalistes, no. 42, 9 December 1909.

Lefébure, Antoine. Havas: les arcanes du pouvoir. Paris: Grasset, 1992.

Le globe, 11 Novembre, 25 Novembre, 2 Decembre, and 9 Decembre 1909.

Leroy-Beaulieu, Paul. L'art de gérer et placer sa fortune. Paris: Ch. Delagrave, 1906.

Lévy-Leboyer, Maurice, and François Bourguignon. L'économie française au XIXème siècle. Analyse macro-économique. Paris: Economica, 1985.

Loustalan, Henri. La Publicité dans la presse française. Pau: Impr. de G. LescherMoutoué, 1933.

Lysis (Letailleur, E.). Contre l'oligarchie financière, 11th edition. Paris: Albin Michel, 1912.

Marinitsch, Oscar. La Bourse théorique et pratique. Paris: Ollendorf, 1892.

McMillan, John, and Pablo Zoido. "How to Subvert Democracy: Montesinos in Peru." Journal of Economic Perspectives 18, no. 4 (2004): 69-92.

Mermet, Emile. La publicité en France. Paris: Imprimerie Chaix, 1878, 1879, 1880. . Annuaire de la presse française. Paris: Mermet, various issues.

Miliukov, Pavel. Russia and Its Crisis. Chicago: Chicago University Press, 1905.

Modiano, René. La presse pourrie aux ordres du capital, Paris: Librairie Populaire. $116 \mathrm{p}, 1935$.

Moron, A. La vérité sur les journaux financiers à bon marché contenant des renseignements indispensables à tous les capitalistes, Nantes. 80 p., 1882.

Mouthon, François-Ignace. Du bluff au chantage - Les grandes campagnes du Matin. Paris: Pauwels, 1908.

Nelson, Phillip. "Information and Consumer Behavior." The Journal of Political Economy 78, no. 2 (1970): 311-29.

. "Advertising as Information." The Journal of Political Economy 82, no. 4 (1974): 729-54.

Neymarck, Alfred. Finances contemporaines. Paris: Félix Alcan, 1911.

$\mathrm{Ng}$, Serena, and Pierre Perron. "Lag Length Selection and the Construction of Unit Root Tests with Good Size and Power." Econometrica 69, no. 6 (2001): 1519-54.

Olson, Mancur. Power and Prosperity: Outgrowing Communist and Capitalist Dictators. New York: Basic Books, 2000.

Olson, Mancur, and Martin C. McGuire. "The Economics of Autocracy and Majority Rule: The Invisible Hand and the Use of Force." Journal of Economic Literature 34, no. 1 (1996): 72-96.

Palmer, Michael B. Des petits journaux aux agences de presse. Naissance du journalisme moderne (1863-1914). Paris: Aubier, 1983.

Petrova, Maria. "Newspapers and Parties: How Advertising Revenues Created an Independent Press." New Economic School Working Paper, August 2009.

Porter, Dilwyn. "A Trusted Guide of the Investing Public: Harry Marks and the Financial News." Business History 28, no. 1 (1986): 1-17.

Raffalovich, Arthur. L'abominable vénalité de la presse. D'après les documents des archives russes, 1897-1917. Paris: Librairie du travail, 1931.

Rajan, R., and Luigi Zingales. "The Great Reversals: The Politics of Financial Development in the Twentieth Century." Journal of Financial Economics 69, no. 1 (2003): 5-50. 
Rochet, Jean-Charles, and Jean Tirole. "Two-Sided Markets: A Progress Report." RAND Journal of Economics 37, no. 3 (2006): 645-67.

Saul, Samir. "Banking Alliances and International Issues on the Paris Capital Market, 1890-1914." In London and Paris as International Financial Centers in the Twentieth Century, edited by Y. Cassis and E. Bussière, 119-50. Oxford: Oxford University Press, 2005.

Shapiro, Carl. "Premiums for High-Quality Products as Returns to Reputations." Quarterly Journal of Economics 98, no. 4 (1983): 659-79.

Simon, Maron J. The Panama Affair. New York: Scribner's, 1971.

Simpson, Antony E. "Dandelions on the Field of Honour: Duelling, the Middle Classes, and the Law in Nineteenth Century England." Criminal Justice History 9 (1988): 99-155.

Smith, Roy C., and Ingo Walter. "Rating Agencies: Is There an Agency Issue?" NYU Working Paper FIN-01-003, 2001.

Soreph, Gustave. Défends ton argent: conseils pratiques pour éviter les pièges tendus à l'épargne. Paris: Larousse, 1909.

Spence, Michael A. "Job Market Signaling." Quarterly Journal of Economics 87, no. 3 (1973): 355-74.

Suzuki, Toshio. Japanese Government Loan Issues on the London Capital Market, 1870-1913. London: Athlone Press, 1994.

Sylla, Richard. "An Historical Primer on the Business of Credit Rating." In Ratings, Rating Agencies, and the Global Financial System, edited by R. Levich, G. Majnoni, and C. Reinhart, 19-40. Boston: Kluwer Academic Publishers, 2002.

Tercentenary Handlist of English and Welsh Newspapers, Magazines, and Reviews, 1620-1920. London: The Times Publishing, 1920.

Trollope, Anthony. The Way We Live Now. London: Chapman, 1875.

Wall Street Journal, 26 March 2009.

Washington Post, 24 November 2004.

Whiting, Bartlett Jere. Early American Proverbs and Proverbial Phrases. Cambridge, MA: Harvard University Press, 1977. 